\title{
Compilation and evaluation of gas phase diffusion coefficients of reactive trace gases in the atmosphere: volume 1. Inorganic compounds
}

\author{
M. J. Tang ${ }^{1,2}$, R. A. Cox ${ }^{1}$, and M. Kalberer ${ }^{1}$ \\ ${ }^{1}$ Department of Chemistry, University of Cambridge, Cambridge CB2 1EW, UK \\ ${ }^{2}$ School of Earth Sciences, University of Bristol, Bristol BS8 1RJ, UK \\ Correspondence to: M. J. Tang (mingjintang@gmail.com) and M. Kalberer (markus.kalberer@atm.ch.cam.ac.uk) \\ Received: 30 May 2014 - Published in Atmos. Chem. Phys. Discuss.: 13 June 2014 \\ Revised: 9 August 2014 - Accepted: 11 August 2014 - Published: 8 September 2014
}

\begin{abstract}
Diffusion of gas molecules to the surface is the first step for all gas-surface reactions. Gas phase diffusion can influence and sometimes even limit the overall rates of these reactions; however, there is no database of the gas phase diffusion coefficients of atmospheric reactive trace gases. Here we compile and evaluate, for the first time, the diffusivities (pressure-independent diffusion coefficients) of atmospheric inorganic reactive trace gases reported in the literature. The measured diffusivities are then compared with estimated values using a semi-empirical method developed by Fuller et al. (1966). The diffusivities estimated using Fuller's method are typically found to be in good agreement with the measured values within $\pm 30 \%$, and therefore Fuller's method can be used to estimate the diffusivities of trace gases for which experimental data are not available. The two experimental methods used in the atmospheric chemistry community to measure the gas phase diffusion coefficients are also discussed. A different version of this compilation/evaluation, which will be updated when new data become available, is uploaded online (https://sites.google.com/ site/mingjintang/home/diffusion).
\end{abstract}

\section{Introduction}

Airborne particles, including aerosol particles, cloud, fog, rain droplets and ice crystals, are ubiquitous in the atmosphere. The interactions of atmospheric trace gases with these particles, i.e. heterogeneous reactions, play important roles in many aspects of atmospheric chemistry (Abbatt et al., 2012; Kolb et al., 2010; Ravishankara, 1997). For example, the heterogeneous reaction of $\mathrm{ClONO}_{2}$ with polar stratospheric clouds (PSCs) is a key step to re-activate chlorine in the stratosphere and thus plays a critical role in stratospheric ozone depletion (Molina, 1996; Solomon, 1999). In the troposphere, the reactions of trace gases with mineral dust (Dentener et al., 1996; Usher et al., 2003), sea salt (FinlaysonPitts, 2003; Rossi, 2003), soot (Monge et al., 2010), organic aerosols (Stemmler et al., 2006), ice particles (Abbatt, 2003; Huthwelker et al., 2006) and liquid cloud droplets (Lelieveld and Crutzen, 1990) can significantly impact the budgets of $\mathrm{NO}_{\mathrm{x}}, \mathrm{O}_{3}$ and $\mathrm{OH}$ radicals. These reactions can also change the compositions of aerosol particles, e.g. mineral dust (Laskin et al., 2005; Sullivan et al., 2007), sea salt (Gard et al., 1998; Rossi, 2003) and organic aerosols (George and Abbatt, 2010), thus modifying their cloud formation ability (Cziczo et al., 2009; Reitz et al., 2011; Sullivan et al., 2009b). The removal, production and/or transformation of gaseous pollutants due to the interactions with indoor surfaces may play an important role in indoor air quality and human health (Nazerroff and Cass, 1989).

Heterogeneous interactions of trace gases with particles in the atmosphere (and with all surfaces) are very complex and usually consist of several steps (Davidovits et al., 2011; Pöschl et al., 2007): (1) gas molecules diffuse towards the surface; (2) gas molecules collide with the surface, and some are then accommodated on the surface; (3) molecules adsorbed on the surface can desorb from the surface, undergo reactions on the surface or diffuse into the bulk, and get dissolved and/or react with other species in the bulk; (4) gaseous 
products formed in the heterogeneous reactions can diffuse towards the surface, desorb from the surface, and finally diffuse into the gas phase. The overall kinetics of a heterogeneous reaction can be described by the uptake coefficient, $\gamma$, which is the net probability that a molecule $\mathrm{X}$ undergoing collision with a surface is actually taken up by the surface. The uptake coefficient links the processes at the interface and beyond with an apparent first-order loss of $\mathrm{X}$ in the gas phase (Ammann et al., 2013; Crowley et al., 2010):

$$
\frac{d[\mathrm{X}]_{\mathrm{g}}}{d t}=-k_{I}[\mathrm{X}]_{\mathrm{g}}=-0.25 \times \gamma \times c(\mathrm{X}) \times[\mathrm{SS}] \times[\mathrm{X}]_{\mathrm{g}},
$$

where $[\mathrm{X}]_{\mathrm{g}}$ is the concentration of $\mathrm{X}$ in the gas phase (molecule $\mathrm{cm}^{-3}$ ), $k_{I}$ is the apparent first-order loss rate of $\mathrm{X}, c(\mathrm{X})$ is the average molecular speed $\left(\mathrm{cm} \mathrm{s}^{-1}\right)$ of $\mathrm{X}$ and [SS] is the concentration of the surface area available for the heterogeneous uptake $\left(\mathrm{cm}^{2} \mathrm{~cm}^{-3}\right)$.

The uptake of a trace gas onto the surface can cause depletion of the trace gas close to the surface, leading to an effective uptake coefficient, $\gamma_{\text {eff }}$, which is smaller than the true uptake coefficient, $\gamma$. The relation between $\gamma_{\text {eff }}$ and $\gamma$, under appropriate steady-state assumptions, can be described by the following equation (Davidovits et al., 1995, 2011):

$$
\frac{1}{r_{\mathrm{eff}}}=\frac{1}{\gamma}+\frac{1}{\Gamma_{\mathrm{diff}}}
$$

where $\Gamma_{\text {diff }}$ describes the gas phase diffusion limitation. Formulas to calculate $\Gamma_{\text {diff }}$ have been derived in previous studies (Davidovits et al., 1995; Pöschl, 2011). $\Gamma_{\text {diff }}$ depends on the geometry of the surface (e.g. surface of a spherical particle, or inner wall of a cylindrical flow tube), the size of the surface (e.g. diameter of the particle or the flow tube) and the diffusion coefficient of the trace gas in the bath gas (Crowley et al., 2010).

For the uptake onto mono-disperse spherical particles, several methods can be used to calculate $\Gamma_{\text {diff }}$ (Pöschl et al., 2007) - for example, the Fuchs-Sutugin equation:

$$
\frac{1}{\Gamma_{\text {diff }}}=\frac{0.75+0.286 K n}{K n \times(K n+1)}
$$

where $K n$ is the Knudsen number, given by

$$
K n=\frac{6 D(\mathrm{X})}{c(\mathrm{X}) \times d_{\mathrm{p}}},
$$

where $D(\mathrm{X})$ is the diffusion coefficient of $\mathrm{X}\left(\mathrm{cm}^{2} \mathrm{~s}^{-1}\right), d_{\mathrm{p}}$ is the diameter of the particle $(\mathrm{cm})$ and $c(\mathrm{X})$ is average molecular speed of $\mathrm{X}\left(\mathrm{cm} \mathrm{s}^{-1}\right)$. For fast uptake processes (i.e. large uptake coefficients) and big particles, gas phase diffusion of $\mathrm{X}$ can limit the overall rate of the uptake of $\mathrm{X}$ onto the surface. A method used to calculate $\Gamma_{\text {diff }}$ for poly-dispersed aerosol particles has also been developed (Tang et al., 2012, 2014). As shown in Eqs. (3) and (4), the diffusion coefficient determines to which extent the effective uptake coefficient is impacted by gas phase diffusion. An accurate knowledge of the diffusion coefficient is thus important to apply the uptake coefficient to atmospheric particles and to derive the true uptake coefficient from the experimentally measured uptake coefficient in laboratory studies. Aerosol flow tubes (Hallquist et al., 2000; Tang et al., 2012; Thornton et al., 2003; Vlasenko et al., 2009), droplet train flow reactors (Deiber et al., 2004; Worsnop et al., 1989) and aerosol chambers (Mogili et al., 2006; Wahner et al., 1998) are widely used to investigate the heterogeneous interaction of airborne particles or droplets with trace gases. The effect of diffusion in the gas phase on the uptake of a trace gas onto spherical particles at 760 Torr $\left(\mathrm{N}_{2}\right)$ and at $296 \mathrm{~K}$ is illustrated in Fig. 1a. $\mathrm{N}_{2} \mathrm{O}_{5}$, with a diffusion coefficient of $0.085 \mathrm{~cm}^{2} \mathrm{~s}^{-1}$ at 760 Torr and at $296 \mathrm{~K}$ (Wagner et al., 2008) and an average molecular speed of $24096 \mathrm{~cm} \mathrm{~s}^{-1}$, is used as the representative trace gas for the calculations. For spherical particles with diameters of $<200 \mathrm{~nm}$, when the true uptake coefficient is $<0.1$, the influence of gas phase diffusion, defined as $\left(\gamma-\gamma_{\text {eff }}\right) / \gamma$, is smaller than $5 \%$. When the true uptake coefficient is $<0.001$, the influence of gas phase diffusion is $<7 \%$ for particles with diameters of $<20 \mu \mathrm{m}$. Increasing the particle diameter and the uptake coefficient will increase the effect of gas phase diffusion, and gas phase diffusion becomes important with $\left(\gamma-\gamma_{\text {eff }}\right) / \gamma$ larger than $20 \%$ for fast uptake $(\gamma>0.04)$ onto larger particles $\left(d_{\mathrm{p}}>2 \mu \mathrm{m}\right)$, as shown in Fig. 1a.

In addition, especially when the heterogeneous reactions of interest are slow, coated or wetted wall flow tubes are used in laboratory studies, in which the solid or liquid substrates form a film on the inner wall of the flow tube to interact with the trace gas under investigation (Abbatt and Molina, 1992; Adams et al., 2005; Hanson et al., 1992; Pouvesle et al., 2010). For the uptake onto the inner wall of a cylindrical tube, $\Gamma_{\text {diff }}$ is given by (Hanson et al., 1992; Wagner et al., 2008)

$$
\frac{1}{\Gamma_{\text {diff }}}=\frac{c(\mathrm{X}) \times d_{t}}{4 \times 3.66 \times D(\mathrm{X})},
$$

where $d_{t}$ is the inner diameter of the flow tube $(\mathrm{cm})$. The quantitative effect of gas phase diffusion on the uptake of a trace gas onto the inner wall of a cylindrical flow tube (inner diameter: $2.0 \mathrm{~cm}$ ) at $296 \mathrm{~K}$ is shown in Fig. $1 \mathrm{~b}$ as a function of pressure $\left(\mathrm{N}_{2}\right) \cdot \mathrm{N}_{2} \mathrm{O}_{5}$ is again used as the representative trace gas. When the true uptake coefficient is $<1 \times 10^{-5}$, the effect of gas phase diffusion is relatively small $(<25 \%)$ even at high pressure (close to $1 \mathrm{~atm}$ ). Increase in the true uptake coefficient enhances the effect of gas phase diffusion. Therefore, in many studies coated-wall flow tubes are operated at low pressures of $\mathrm{He}$, to increase the gas phase diffusion rate and thus suppress the effect of gas phase diffusion on the overall effective uptake rate. When the true uptake coefficient is close to 0.1, as shown in Fig. 1b, the uptake onto the wall is entirely controlled by gas phase diffusion $\left(\gamma_{\text {eff }} / \gamma\right.$ is $\sim 0.1$ ) and therefore the upper limit for accurate uptake measurement using this method is around 0.1. Another type of coated wall flow tube in which the solid substance under 


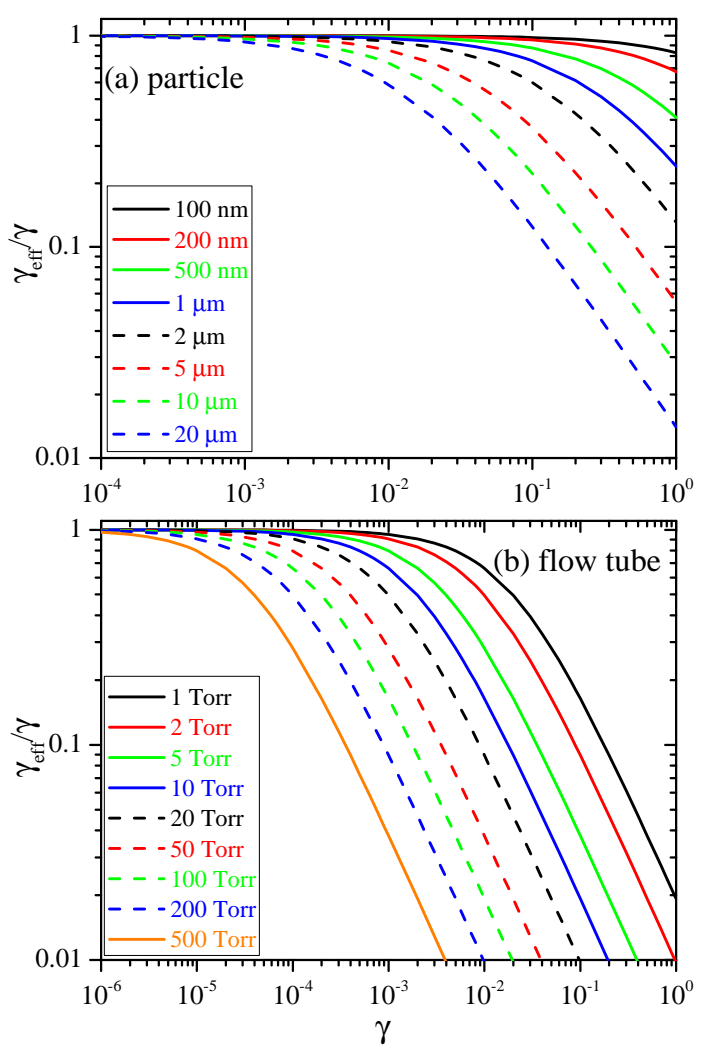

Figure 1. Influence of gas phase diffusion on the effective uptake coefficients (defined as $\gamma_{\text {eff }} / \gamma$, the ratio of the effective uptake to the true uptake coefficient) as a function of the true uptake coefficient. $\mathrm{N}_{2} \mathrm{O}_{5}$, with a diffusion coefficient of $0.085 \mathrm{~cm}^{2} \mathrm{~s}^{-1}$ at 760 Torr and $296 \mathrm{~K}$ and an average molecular speed of $24096 \mathrm{~cm} \mathrm{~s}^{-1}$, is used as the representative trace gas for the calculations. (a) Uptake onto spheric particles with different diameters at 760 Torr and $296 \mathrm{~K}$; (b) uptake onto the wall of a cylindrical flow tube (inner diameter: $2.0 \mathrm{~cm}$ ) at $296 \mathrm{~K}$ and at different pressures.

investigation is coated on the outer wall of the injector instead of the inner wall of the flow reactor has also be used (Bedjanian et al., 2005; Gershenzon et al., 1995), and details on how to derive $\gamma$ from $\gamma_{\text {eff }}$ are provided by Gershenzon et al. (1995).

The interaction of trace gases with surfaces, and therefore gas phase diffusion coefficients, are not only important in the investigation of atmospheric heterogeneous reactions, but are also important to describe the efficiency of diffusion denuders which are widely used to collect trace gases or to separate trace gases from aerosol particles. For example, denuder tubes in which inner walls are coated with adsorbents are widely used to capture trace gases such as $\mathrm{HNO}_{3}$ (Braman et al., 1982; Durham et al., 1987; Eatough et al., 1985), HONO (Ferm and Sjodin, 1985) and $\mathrm{NH}_{3}$ (Braman et al., 1982) for online/offline analysis, and to separate aerosol particles from gases (e.g. to separate $\mathrm{NH}_{3}$ from particulate $\mathrm{NH}_{4}^{+}$). Aerosol particles which remain in the flow exiting the denuders can then be collected for further online/offline analysis, and artifacts due to interferences of trace gases (for example, particulate nitrate versus gaseous $\mathrm{HNO}_{3}$, and ammonium versus $\mathrm{NH}_{3}$ ) can be minimised (Ferm, 1986). Denuders are also widely used in laboratory studies to remove reactive trace gases to terminate heterogeneous reactions (Sullivan et al., 2009a), or selectively remove reactive trace gases whose detection can interfere with others (Ammann et al., 1998). In addition, catalytic tubes are used to convert trace gases to products which can then be more easily detected. For example, the widely used chemiluminescence method to measure $\mathrm{NO}_{2}$ is based on conversion of $\mathrm{NO}_{2}$ to $\mathrm{NO}$ in a catalytic conversion tube coated with metal films such as nickel or gold (Fahey et al., 1985). The removal and/or conversion of trace gases in a denuder or catalytic tubes requires the diffusion of trace gases towards and collision with the inner wall, and therefore the knowledge of diffusion coefficients is helpful for the optimisation of the design of denuder and catalytic conversion tubes (Murphy and Fahey, 1987).

The importance of further research on atmospheric heterogeneous reactions has been underscored (Abbatt et al., 2014; Kolb et al., 2010), the necessity of adopting consistent terminology, formalism and parameters in the heterogeneous reaction studies has been highlighted (Kolb et al., 2010; Pöschl et al., 2007), and comprehensive models have been developed to take into account all the steps involved in heterogeneous reactions (Pöschl et al., 2007; Shiraiwa et al., 2010). Two independent international panels, the IUPAC Subcommittee for Gas Kinetic Data Evaluation (Ammann et al., 2013; Crowley et al., 2010) and the NASA/JPL Panel for Data Evaluation (Sander et al., 2011) have been evaluating and recommending the experimental kinetic data for atmospheric heterogeneous reactions. However, gas phase diffusion coefficients of atmospheric reactive trace gases have only been occasionally measured during the investigation of heterogeneous reactions and development of denuder methods. To the best of our knowledge, these data have not been compiled previously. When unavailable, these values have to be estimated, and even sometimes were arbitrarily chosen, leading to additional errors. Therefore, a compilation and/or evaluation of measured diffusion coefficients is clearly required. We note that there are several databases on the binary gas phase diffusion coefficients (Berezhnoi and Semenov, 1997; Gordon, 1977; Marrero and Mason, 1972); however, the existing databases focus on stable gases which are of limited relevance for atmospheric chemistry.

Here we compile and evaluate the diffusion coefficients of atmospheric inorganic reactive trace gases reported in the literature, with the hope that this work will enhance the dissemination of the reported diffusion coefficients and stimulate further experimental measurements. We also compare the measured values to those estimated using Fuller's method, in order to evaluate the performance of this method. Fuller's method is a semi-empirical method to directly estimate the gas phase diffusivities (Fuller et al., 1966, 1969). 
The diffusivities of organic species are beyond the scope of this paper (the only included organic molecule is $\mathrm{CH}_{3} \mathrm{SO}_{3} \mathrm{H}$ ). The uptake of organics, particularly oxygenated organics, onto aerosol particles and cloud droplets can also be important in the atmosphere. We have started to compile and evaluate the diffusion coefficients of organic species of atmospheric interest, and plan to publish another review in the near future. Marrero and Mason (1972) compiled the diffusivities of some alcohols, ketones, aldehyde and carbonic acids, though many of them may not be of direct atmospheric interest.

\section{Methodology}

\subsection{Gas phase diffusivity}

The theory describing diffusion in binary gas mixtures at low to moderate pressure can be derived by solving the Boltzmann equation, and the diffusion coefficient can be expressed as (Reid et al., 1987)

$D(\mathrm{~A}, \mathrm{~B}, P)=\frac{0.00266 T^{1.5}}{P \sqrt{M(\mathrm{~A}, \mathrm{~B})} \sigma^{2} \Omega_{\mathrm{D}}}$,

where $D(\mathrm{~A}, \mathrm{~B}, P)$ is the diffusion coefficient $\left(\mathrm{cm}^{2} \mathrm{~s}^{-1}\right)$ of gas A in gas $\mathrm{B}$ at a pressure of $P$ (bar), $T$ is the temperature $(\mathrm{K}), M(\mathrm{~A}, \mathrm{~B})$ is equal to twice of the reduced mass of molecule A and molecule $\mathrm{B}, \sigma$ is the characteristic length $\left(10^{-1} \mathrm{~nm}\right)$, and $\Omega_{\mathrm{D}}$ is the dimensionless diffusion collision integral. To derive Eq. (6), it is also assumed that the gases investigated obey the ideal-gas law and gas A is only present in trace amount compared to B.

To estimate diffusion coefficients using Eq. (6), the values of $\sigma$ and $\Omega_{\mathrm{D}}$ need to be calculated/estimated. Ghosal (1993) used the Lennard-Jones method to estimate the diffusion coefficients of a variety of atmospheric trace gases, and Ivanov et al. (2007) found that the diffusion coefficients of $\mathrm{OH}, \mathrm{HO}_{2}$, and $\mathrm{O}_{3}$ estimated by the Lennard-Jones method agree well with their experimentally measured values. However, to calculate $\sigma$ and $\Omega_{\mathrm{D}}$, the Lennard-Jones method requires molecular parameters which are not readily available.

Several empirical/semi-empirical methods are available to directly estimate diffusion coefficient, e.g. the method proposed by Fuller et al. (1966, 1969). Reid et al. (1987) compared the estimated diffusion coefficients of a large range of molecules using different methods, including the LennardJones method and Fuller's method, with measured values, and found that Fuller's method in general yields the smallest errors. Therefore, in this work Fuller's method is used.

\subsubsection{Fuller's method}

Measured gas phase diffusion coefficients, $D(\mathrm{~A}, \mathrm{~B}, P)$, usually reported in $\mathrm{cm}^{2} \mathrm{~s}^{-1}$, depend on the pressure under which the diffusion coefficients were measured. Pressureindependent diffusion coefficients $\left(\right.$ torr $\left.\mathrm{cm}^{2} \mathrm{~s}^{-1}\right), D(\mathrm{~A}, \mathrm{~B})$, sometimes called diffusivities, are reported by dividing $D$ (A, $\mathrm{B}, P)$ by the pressure. In this work for clarity and consistency, the pressure-independent diffusion coefficient, $D(\mathrm{~A}$, $\mathrm{B})$, is referred to as diffusivity, and all the reported diffusion coefficients are converted to diffusivities.

The diffusivity of gas A in gas B, estimated using Fuller's method, can be described by (Fuller et al., 1966, 1969)

$D(\mathrm{~A}, \mathrm{~B})=\frac{1.0868 \times T^{1.75}}{\sqrt{m(\mathrm{~A}, \mathrm{~B})}\left(\sqrt[3]{V_{\mathrm{A}}}+\sqrt[3]{V_{\mathrm{B}}}\right)^{2}}$,

where $D(\mathrm{~A}, \mathrm{~B})$ is the diffusivity of $\mathrm{A}$ in $\mathrm{B}\left(\right.$ Torr $\left.\mathrm{cm}^{2} \mathrm{~s}^{-1}\right)$ at the temperature of $T(\mathrm{~K})$, and $m(\mathrm{~A}, \mathrm{~B})\left(\mathrm{g} \mathrm{mol}^{-1}\right)$ is given by

$m(\mathrm{~A}, \mathrm{~B})=\frac{2}{\left(1 / m_{\mathrm{A}}+1 / m_{\mathrm{B}}\right)}$

where $m_{\mathrm{A}}$ and $m_{\mathrm{B}}$ are the molecular weights $\left(\mathrm{g} \mathrm{mol}^{-1}\right)$ of A and $\mathrm{B}$, and $V_{\mathrm{A}}$ and $V_{\mathrm{B}}$ are the dimensionless diffusion volumes of A and B, respectively. Pressure is given in Torr instead of SI units (e.g. Pa) in this work, because Torr is widely used as the pressure unit in flow tube studies and many diffusivities are reported in Torr $\mathrm{cm}^{2} \mathrm{~s}^{-1}$. The dimensionless diffusion volumes of a few simple molecules, including $\mathrm{N}_{2}, \mathrm{O}_{2}$, $\mathrm{He}, \mathrm{H}_{2} \mathrm{O}, \mathrm{NH}_{3}, \mathrm{SO}_{2}, \mathrm{Cl}_{2}$, and $\mathrm{Br}_{2}$, are listed in Table 1, and the diffusion volume of air is 19.7. The diffusion volume of a molecule, if not listed in Table 1, can be calculated by summing the diffusion volumes of all the atoms it contains:

$V=\sum n_{i} V_{i}$,

where $n_{i}$ is the number of the atom with a diffusion volume of $V_{i}$ contained by the molecule. The diffusion volumes of a few atoms of atmospheric interest are listed in Table 1. Readers are referred to Table 11-1 of Reid et al. (1987) for the diffusion volumes of other molecules and atoms not included in Table 1 of this paper.

The atomic diffusion volumes are determined by regression analysis of experimental data on gas phase diffusion coefficients of a large range of molecules. Calculation of molecular diffusion volumes from atomic diffusion volumes may lead to different errors for different molecules. The diffusion volume of $\mathrm{SO}_{2}$ would be 35.12 if derived from atomic diffusion volumes according to Eq. (9), and it is 41.8 (as listed in Table 1) which is directly calculated from extensive experimental data set of gas phase diffusivities of $\mathrm{SO}_{2}$. As shown in Tables 2-5, we find that, compared to the experimental values, the diffusivities estimated using Fuller's method are typically $20-50 \%$ larger for atmospheric trace gases that we include in this work. We suggest that this mainly results from underestimation of molecular diffusion volumes derived from atomic diffusion volumes.

The diffusion of a trace gas, $\mathrm{A}$, in the binary mixture of $\mathrm{B} 1$ (e.g. $\mathrm{N}_{2}$ ) and $\mathrm{B} 2\left(\right.$ e.g. $\mathrm{H}_{2} \mathrm{O}$ ), can be calculated as (Reid et al., 1987; Fickert et al., 1999)

$\frac{1}{D(\mathrm{~A}, \mathrm{~B} 1, \mathrm{~B} 2)}=\frac{x(\mathrm{~B} 1)}{D(\mathrm{~A}, \mathrm{~B} 1)}+\frac{x(\mathrm{~B} 2)}{D(\mathrm{~A}, \mathrm{~B} 2)}$, 
Table 1. Dimensionless diffusion volumes of molecules and atoms of atmospheric interest. Data are taken from Table 11-1 of Reid et al. (1987).

\begin{tabular}{lllll}
\hline \multicolumn{5}{c}{ Molecules } \\
\hline Species & $\mathrm{N}_{2}$ & $\mathrm{O}_{2}$ & $\mathrm{He}$ & $\mathrm{H}_{2} \mathrm{O}$ \\
\hline Diffusion volume & 18.5 & 16.3 & 2.67 & 13.1 \\
Species & $\mathrm{NH}_{3}$ & $\mathrm{SO}_{2}$ & $\mathrm{Cl}_{2}$ & $\mathrm{Br}_{2}$ \\
Diffusion volume & 20.7 & 41.8 & 38.4 & 69 \\
\hline & Atoms & & \\
\hline Species & $\mathrm{C}$ & $\mathrm{H}$ & $\mathrm{O}$ & $\mathrm{N}$ \\
Diffusion volume & 15.9 & 2.31 & 6.11 & 4.54 \\
Species & $\mathrm{Cl}$ & $\mathrm{Br}$ & $\mathrm{I}$ & $\mathrm{S}$ \\
Diffusion volume & 21 & 21.9 & 29.8 & 22.9 \\
\hline
\end{tabular}

where $x(\mathrm{~B} 1)$ and $x(\mathrm{~B} 2)$ are the molar fractions of $\mathrm{B} 1$ and $\mathrm{B} 2$ in the mixture, $D(\mathrm{~A}, \mathrm{~B} 1, \mathrm{~B} 2), D(\mathrm{~A}, \mathrm{~B} 1)$ and $D(\mathrm{~A}, \mathrm{~B} 2)$ are the diffusivities of $\mathrm{A}$ in the binary mixture (of B1 and B2), B1, and $\mathrm{B} 2$, respectively.

\subsection{Measurements of diffusion coefficients}

Gas phase diffusion coefficients have been measured since the late 19th century, and many experimental methods have been developed (Marrero and Mason, 1972); however, most (if not all) of these methods can only by applied to relatively stable gases and thus are not suitable for determining the diffusivities of atmospheric reactive trace gases. To our knowledge only two methods, i.e. flow tubes and denuders, have been used to measure the diffusivities of trace gases by the atmospheric chemistry community. Both methods use the same principle: a flow containing the trace gas is delivered through a tube (usually cylindrical) which is coated on its inner wall with a very reactive substance and thus serves as a perfect sink for trace gas molecules colliding with the wall. Therefore, the overall loss rate of the trace gas is entirely controlled by its diffusion in the gas phase towards the wall and not influenced by the reactivity of the surface. The two methods are briefly discussed below.

\subsubsection{Flow tubes}

If the inner wall of a cylindrical flow tube is very reactive towards the trace gas, the loss rate of the trace gas onto the wall can then be used to determine the gas phase diffusion coefficient. Under laminar flow conditions, $D(\mathrm{~A}, \mathrm{~B}, P)$ can be related to the measured wall loss rate, $k_{\mathrm{w}}$, by

$D(\mathrm{~A}, \mathrm{~B}, P)=\frac{k_{\mathrm{w}} r_{t}^{2}}{3.66}$,

where $r_{t}$ is the radius of the flow tube (Zasypkin et al., 1997). This equation is only valid for conditions under which the Peclet number, $P e$, is larger than 20 (Zasypkin et al., 1997).
$P e$ is given by

$P e=\frac{2 r_{t} v}{D(\mathrm{~A}, \mathrm{~B}, P)}$,

where $v$ is the linear flow velocity in the flow tube. It is necessary to measure $D(\mathrm{~A}, \mathrm{~B}, P)$ at different pressure to derive the diffusivity, $D(\mathrm{~A}, \mathrm{~B})$. If the wall serves as a perfect sink for the trace gas, $D(\mathrm{~A}, \mathrm{~B})$ measured at different pressure should show good agreement (Fickert et al., 1999; Liu et al., 2009).

\subsubsection{Denuders}

A laminar flow containing stable mixing ratios of the trace gas passes through the denuder which consists of several sections with the same length. The trace gas is collected on the inner wall of each section and converted to a stable adsorbate, which is then quantified offline to determine the collection efficiency, $E$ (Ferm and Sjodin, 1985):

$E=\frac{c_{i}-c_{i+1}}{c_{i}}$,

where $c_{i}$ and $c_{i+1}$ are the amount of adsorbate being collected on the $i$ th and $(i+1)$ th sections, respectively. For a cylindrical tube whose inner wall acts as a perfect sink for the trace gas, $E$ can be related to the diffusion coefficient, $D(\mathrm{~A}, \mathrm{~B}, P)$ by

$$
\begin{aligned}
& 1-E=0.819 \times 10^{-11.489 \Delta}+0.0975 \times 10^{-70.1 \Delta} \\
& -0.0325 \times 10^{-179 \Delta} \\
& \Delta=\frac{D(\mathrm{~A}, \mathrm{~B}, P) \times L}{F},
\end{aligned}
$$

where $L$ is the length of each section of the denuder $(\mathrm{cm})$, and $F$ is the volume flow rate of the flow passing through the denuder $\left(\mathrm{cm}^{3} \mathrm{~s}^{-1}\right)$ (Ferm and Sjodin, 1985).

It is important for both methods to ensure that the wall remains as a perfect sink for the trace gas during the experiment so that the overall loss of the trace gas is controlled by 
gas phase diffusion. In a flow tube experiment, this can be checked be measuring the diffusion coefficients at different pressures over a broad range (Fickert et al., 1999; Ivanov et al., 2007). A denuder is normally operated at constant pressure (close to atmospheric pressure) and therefore it is often not verified whether the inner wall of the denuder is a perfect sink. Fast-response online detectors are often available to measure the decay of trace gases in a flow tube, enabling relatively quick determination of the diffusivities. The denuder method usually requires a substantial period to collect enough samples which will then be post-processed and analysed, making it quite laborious. Therefore, the flow tube method appears to be a better method for the determination of diffusivities in the gas phase. We recommend that such measurements should be performed over a broad range of pressure, in order to ensure that the inner wall serves as a perfect sink.

\section{Results}

The recommended diffusivities in air are summarised in Table 2. Since the diffusivity of a trace gas in air is approximately the same as its diffusivity in $\mathrm{N}_{2} / \mathrm{O}_{2}$, no adjustment was made if measurements were performed in $\mathrm{N}_{2} / \mathrm{O}_{2}$ instead of air. The diffusivities of some important reactive trace gases in air (or in $\mathrm{N}_{2} / \mathrm{O}_{2}$ ), e.g. $\mathrm{HO}_{2}, \mathrm{O}_{3}, \mathrm{HOCl}$ and $\mathrm{ClONO}_{2}$, have not been experimentally determined, and therefore no recommendation can be made. However, these species are listed in Table 2 to highlight the urgency to measure their diffusivities. A different version of this compilation/evaluation, which largely follows the format of online reports prepared by the IUPAC Task Group on Atmospheric Chemical Kinetic Data Evaluation (http://iupac. pole-ether.fr/), is uploaded online (https://sites.google.com/ site/mingjintang/home/diffusion) and will be updated when new data are available.

For trace gases whose diffusivities were measured under the same (or similar) conditions by more than one study, the preferred diffusivity is the average of the measured values and the given uncertainty is the corresponding standard deviation, after excluding studies whose results appear significantly different. However, except for a few trace gases (e.g. $\mathrm{HNO}_{3}$ and $\mathrm{NH}_{3}$ ), the diffusivities of most trace gases have only been reported by one study. If there is only one experimental value available, the experimental value is temporarily preferred, and the given uncertainty reflects the difference between the measured and estimated diffusivities, e.g. if the estimated diffusivity is $30 \%$ larger than the measured value, an uncertainty of $\pm 30 \%$ is given to the preferred value.

Preferred diffusivities in air (or $\mathrm{N}_{2} / \mathrm{O}_{2}$ ) at $296 \mathrm{~K}$ are recommended. If the measurement was not carried out at $296 \mathrm{~K}$, the original diffusivity was adjusted to $296 \mathrm{~K}$, assuming that the temperature dependence can be described by Fuller's method:

$D(296)=D(T) \times\left(\frac{296}{T}\right)^{1.75}$,

where $T$ is the temperature $(\mathrm{K})$ at which the measurement was performed, and $D(296)$ and $D(T)$ are the diffusivities at the temperature of $296 \mathrm{~K}$ and $T$, respectively. If the difference between $T$ and $296 \mathrm{~K}$ is $\leq 10 \mathrm{~K}$, the difference in the diffusivities is not larger than $6 \%$ which is negligible compared to the uncertainties of reported diffusivities, and thus no adjustment due to temperature difference was performed.

In the following sections, we compile and discuss experimental gas phase diffusivities reported in the literature, and compare them to estimated values using Fuller's method. Diffusivities for individual molecules are then recommended if possible.

\section{1 $\mathrm{HNO}_{3}$ and $\mathrm{NH}_{3}$}

The diffusivities of $\mathrm{HNO}_{3}$ were all measured by using denuders at 296-298 K. As shown in Table 3, all the reported values agree well with each other except a much smaller value reported by De Andrade et al. (1992). The preferred diffusivity of $\mathrm{HNO}_{3}$ in air at $296 \mathrm{~K},(87 \pm 7)$ Torr $\mathrm{cm}^{2} \mathrm{~s}^{-1}$, is the average value of all the measurements except De Andrade et al. (1992). On average the estimated diffusivity using Fuller's method is $\sim 30 \%$ larger than the measured values.

As shown in Table 3, the diffusivity of $\mathrm{NH}_{3}$ in $\mathrm{N}_{2}$ (or air $/ \mathrm{O}_{2}$ ) was measured over a wide temperature range (293-523 K) prior to 1960 , and the reported values at $296-$ $298 \mathrm{~K}$ agree very well with more recent measurements in $\mathrm{N}_{2}$ using flow tubes (Hanson and Kosciuch, 2003) and denuders (Braman et al., 1982; Spiller et al., 1989). The preferred diffusivity of $\mathrm{NH}_{3}$ in $\mathrm{N}_{2}$ (or air/ $\mathrm{O}_{2}$ ) at $296 \mathrm{~K}$, $(176 \pm 10)$ Torr $\mathrm{cm}^{2} \mathrm{~s}^{-1}$, is the average of those reported by all the studies at this temperature. The estimated diffusivities using Fuller's method agree very well with the measured ones.

\section{2 $\mathrm{NO}, \mathrm{NO}_{2}, \mathrm{NO}_{3}, \mathrm{~N}_{2} \mathrm{O}_{5}$ and $\mathrm{HONO}$}

The diffusivities of $\mathrm{NO}$ and $\mathrm{N}_{2} \mathrm{O}_{5}$ in $\mathrm{N}_{2}$ were only determined once, to the best of our knowledge. The results are listed in Table 4. The estimated diffusivities using Fuller's method are $2 \%$ higher than the measured values for NO, and $45 \%$ for $\mathrm{N}_{2} \mathrm{O}_{5}$. Since their diffusivities were only reported once and the measured values agree reasonably well with estimates using Fuller's method, the reported values are preferred. Uncertainties of $\pm 10 \%$ and $\pm 50 \%$ are given to the preferred diffusivities of $\mathrm{NO}$ and $\mathrm{N}_{2} \mathrm{O}_{5}$, reflecting the difference between the measurement and the estimation. More measurements are needed to reduce the relatively large uncertainty of the diffusivity of $\mathrm{N}_{2} \mathrm{O}_{5}$, considering the importance of its uptake onto airborne particles in both the troposphere and the stratosphere. 
Table 2. Summary of preferred diffusivities of atmospheric reactive trace gases in air at 296 K. Several trace gases without recommended diffusivities are also listed to highlight the necessity of further measurements.

\begin{tabular}{|c|c|c|c|}
\hline Species & $\begin{array}{c}\text { Diffusivity } \\
\left(\text { Torr } \mathrm{cm}^{2} \mathrm{~s}^{-1}\right)\end{array}$ & Species & $\begin{array}{c}\text { Diffusivity } \\
\left(\text { Torr } \mathrm{cm}^{2} \mathrm{~s}^{-1}\right)\end{array}$ \\
\hline $\mathrm{HNO}_{3}$ & $87 \pm 7$ & $\mathrm{NH}_{3}$ & $176 \pm 10$ \\
\hline NO & $176 \pm 18$ & $\mathrm{NO}_{2}$ & $106 \pm 37$ \\
\hline $\mathrm{NO}_{3}$ & $92 \pm 46$ & $\mathrm{~N}_{2} \mathrm{O}_{5}$ & $65 \pm 33$ \\
\hline HONO & $96 \pm 26$ & & \\
\hline $\mathrm{SO}_{2}$ & $94 \pm 13$ & $\mathrm{SO}_{3}$ & $91 \pm 6$ \\
\hline $\mathrm{H}_{2} \mathrm{SO}_{4}$ & $74 \pm 10$ & $\mathrm{CH}_{3} \mathrm{SO}_{3} \mathrm{H}$ & $60 \pm 18$ \\
\hline $\mathrm{OH}$ & $178 \pm 20$ & $\mathrm{HO}_{2}$ & n.m. \\
\hline $\mathrm{H}_{2} \mathrm{O}_{2}$ & $116 \pm 35$ & $\mathrm{O}_{3}$ & n.m. \\
\hline $\mathrm{HOCl}$ & n.m. & $\mathrm{HOBr}$ & $84 \pm 9$ \\
\hline HOI & n.m. & $\mathrm{HCl}$ & $118 \pm 7$ \\
\hline $\mathrm{HBr}$ & $95 \pm 29$ & $\mathrm{HI}$ & n.m. \\
\hline $\begin{array}{l}\mathrm{ClONO}_{2} \\
\mathrm{BrONO}_{2}\end{array}$ & n.m. & $\mathrm{ClNO}_{2}$ & $85 \pm 17$ \\
\hline $\mathrm{Cl}_{2}$ & $94 \pm 10$ & & $75 \pm 6$ \\
\hline $\mathrm{I}_{2}$ & $53 \pm 13$ & $\mathrm{BrCl}$ & n.m. \\
\hline $\mathrm{ICl}$ & n.m. & & \\
\hline
\end{tabular}

n.m.: no measurements available

The diffusivity of $\mathrm{NO}_{2}$ in $\mathrm{N}_{2}$ was measured once by Chambers and Sherwood (1937). A high partial pressure of $\mathrm{NO}_{2}$ was used in the experiment and therefore the presence of $\mathrm{N}_{2} \mathrm{O}_{4}$ in the system was significant. The diffusivity of $\mathrm{NO}_{2}$ was experimentally determined by assuming that the diffusivity of $\mathrm{NO}_{2}$ is a factor of 1.43 of that of $\mathrm{N}_{2} \mathrm{O}_{4}$. The measurements were carried out at two different temperatures, and the estimated diffusivities using Fuller's method are $35 \%$ larger than the measured values, as shown in Table 4. The preferred diffusivity of $\mathrm{NO}_{2}$ in $\mathrm{N}_{2}$ at $296 \mathrm{~K}$, $(106 \pm 37)$ Torr $\mathrm{cm}^{2} \mathrm{~s}^{-1}$, is based on the value reported at $283 \mathrm{~K}$ by Chambers and Sherwood (1937), extrapolated to $296 \mathrm{~K}$. The given uncertainty $( \pm 35 \%)$ reflects the difference between the measurement and the estimation at $283 \mathrm{~K}$.

The diffusivities of $\mathrm{NO}_{3}$ radicals in $\mathrm{N}_{2}, \mathrm{O}_{2}, \mathrm{He}$ and $\mathrm{H}_{2} \mathrm{O}$ were determined using a flow tube (Rudich et al., 1996). The measured diffusivity in $\mathrm{N}_{2}$, as expected, agrees very well with that in $\mathrm{O}_{2}$. The estimated diffusivities using Fuller's method are $50 \%$ larger than the measured values for $\mathrm{NO}_{3}$ radicals. The preferred diffusivity of $\mathrm{NO}_{3}$ radicals in $\mathrm{N}_{2}$ at $296 \mathrm{~K},(92 \pm 46)$ Torr $\mathrm{cm}^{2} \mathrm{~s}^{-1}$, is based on the measurement of Rudich et al. (1996) at $273 \mathrm{~K}$ and extrapolated to $296 \mathrm{~K}$ using Eq. (16). The large uncertainty we give to the preferred value reflects the relatively significant difference between the measurement and the estimation using Fuller's method, and highlights that further measurements are desired.

The diffusivity of HONO in $\mathrm{He}$ was measured to be (433 \pm 38 ) Torr $\mathrm{cm}^{2} \mathrm{~s}^{-1}$ at $294 \mathrm{~K}$ (Hirokawa et al., 2008) and $(490 \pm 50)$ Torr $\mathrm{cm}^{2} \mathrm{~s}^{-1}$ at $300 \mathrm{~K}$ (El Zein and Bedjanian,
2012) using flow tubes, as listed in Table 4. The two studies are in good agreement, and differences between the measured and estimated diffusivities are $<20 \%$. The diffusivity of HONO in air at $298 \mathrm{~K}$ reported by Benner et al. (1988) is significantly smaller than that reported at $296 \mathrm{~K}$ by Ferm and Sjodin (Ferm and Sjodin, 1985), though denuders were used in both studies. The preferred diffusivity of HONO in air at $296 \mathrm{~K},(96 \pm 26)$ Torr $\mathrm{cm}^{2} \mathrm{~s}^{-1}$, is the average of those reported by the two studies (Benner et al., 1988; Ferm and Sjodin, 1985). Since the difference between the two studies is statistically significant, further studies, preferably using a flow tube, are needed to reduce the uncertainty of the diffusivity of $\mathrm{HONO}$ in air (or $\mathrm{N}_{2}, \mathrm{O}_{2}$ ).

\section{3 $\mathrm{SO}_{2}, \mathrm{SO}_{3}, \mathrm{H}_{2} \mathrm{SO}_{4}$, and $\mathrm{CH}_{3} \mathrm{SO}_{3} \mathrm{H}$}

The diffusivity of $\mathrm{SO}_{2}$ in air was measured at $263 \mathrm{~K}$ (Mason and Monchick, 1962), $293 \mathrm{~K}$ (Andrew, 1995), and $298 \mathrm{~K}$ (Fish and Durham, 1971). The reported values in these three studies agree well with the estimates using Fuller's method, as shown in Table 5. The preferred diffusivity of $\mathrm{SO}_{2}$ in air at $296 \mathrm{~K},(94 \pm 13)$ Torr $\mathrm{cm}^{2} \mathrm{~s}^{-1}$, is the average of the values measured by Andrew (1955) and Fish and Durham (1971) at room temperature.

The diffusivity of $\mathrm{SO}_{3}$ in $\mathrm{N}_{2}$ was measured at $295 \mathrm{~K}$ by Lovejoy and Hanson (1996) and at $300 \mathrm{~K}$ by Jayne et al. (1998), both using flow tubes. The measured diffusivities agree well with each other, and are also in good agreement with the estimated values. The preferred diffusivity of 
Table 3. Summary of measured diffusivities of $\mathrm{HNO}_{3}$ and $\mathrm{NH}_{3}$, and comparison with the estimated values.

\begin{tabular}{|c|c|c|c|c|c|c|}
\hline $\begin{array}{l}\text { Trace } \\
\text { gas }\end{array}$ & $\begin{array}{l}\text { Bath } \\
\text { gas }\end{array}$ & Reference & $\begin{array}{c}T \\
(\mathrm{~K})\end{array}$ & $D_{\mathrm{m}}$ & $D_{\mathrm{e}}$ & $\begin{array}{r}\left(D_{\mathrm{e}}-D_{\mathrm{m}}\right) / \\
D_{\mathrm{m}}(\%)\end{array}$ \\
\hline \multirow[t]{6}{*}{$\mathrm{HNO}_{3}$} & \multirow[t]{6}{*}{ air } & $\mathrm{a}$ & 296 & $92 \pm 12$ & 116 & 26 \\
\hline & & $\mathrm{b}$ & 296 & $79 \pm 8$ & 116 & 47 \\
\hline & & $\mathrm{c}$ & 296 & $91 \pm 11$ & 116 & 27 \\
\hline & & d & 298 & $90 \pm 2$ & 116 & 29 \\
\hline & & $\mathrm{e}$ & 296 & $81 \pm 12$ & 116 & 43 \\
\hline & & $\mathrm{f}$ & 298 & $31 \pm 1$ & 116 & 274 \\
\hline \multirow[t]{16}{*}{$\mathrm{NH}_{3}$} & \multirow[t]{9}{*}{$\mathrm{N}_{2}$} & $\mathrm{~g}$ & 293 & 183 & 169 & -8 \\
\hline & & $\mathrm{h}$ & 298 & 175 & 174 & -1 \\
\hline & & $\mathrm{h}$ & 328 & 217 & 206 & -5 \\
\hline & & $\mathrm{h}$ & 358 & 249 & 240 & -4 \\
\hline & & i & 293 & $167 \pm 1$ & 169 & 1 \\
\hline & & $\mathrm{i}$ & 373 & $258 \pm 1$ & 257 & 0 \\
\hline & & $\mathrm{i}$ & 473 & $394 \pm 1$ & 390 & -1 \\
\hline & & $\mathrm{i}$ & 523 & $468 \pm 1$ & 465 & -1 \\
\hline & & $\mathrm{j}$ & 296 & $167 \pm 12$ & 172 & 3 \\
\hline & \multirow[t]{4}{*}{$\mathrm{O}_{2}$} & $\mathrm{~g}$ & 293 & 192 & 172 & -10 \\
\hline & & $\mathrm{i}$ & 293 & $173 \pm 1$ & 172 & -1 \\
\hline & & $\mathrm{i}$ & 373 & $266 \pm 1$ & 262 & -2 \\
\hline & & $\mathrm{i}$ & 473 & $404 \pm 1$ & 397 & -2 \\
\hline & \multirow[t]{3}{*}{ air } & $\mathrm{k}$ & 293 & $173 \pm 6$ & 172 & -1 \\
\hline & & $\mathrm{a}$ & 296 & $180 \pm 12$ & 167 & -7 \\
\hline & & 1 & 298 & $173 \pm 9$ & 169 & -2 \\
\hline $\begin{array}{l}D_{\mathrm{m}} \text { : measu } \\
{ }^{\mathrm{a}} \text { Braman e } \\
(1986) ;{ }^{\mathrm{e}} \mathrm{B} \\
\text { Mason and } \\
(1955) ;{ }^{1} \mathrm{~S} p\end{array}$ & $\begin{array}{l}\text { diffusiv } \\
\text { (1982) } \\
\text { et et al. } \\
\text { achick } \\
\text { (1989 }\end{array}$ & $\begin{array}{l}\text { ty (Torr } \mathrm{cm}^{2} \mathrm{~s}^{-1} \\
\text { b Eatough et al. } \\
\text { 1988); }{ }^{\mathrm{f}} \text { De And } \\
\text { 1962); }{ }^{\mathrm{i}} \text { Weissm }\end{array}$ & $\begin{array}{l}D \mathrm{e}: \text { es } \\
855) ;{ }^{\circ} \\
\text { de et a }\end{array}$ & $\begin{array}{l}\text { hated diffusiv } \\
\text { erm (1986); }{ }^{d} \\
\text { 1992); }{ }^{\mathrm{g}} \text { Trat } \\
\text { Hanson and }\end{array}$ & $\begin{array}{l}\text { (Tor } \\
\text { urhan } \\
\text { and I }\end{array}$ & $\begin{array}{l}\mathrm{l}^{-1} \text { ). } \\
\text { d Stockburger } \\
\text { ler (1935); } \\
\text { 003); }{ }^{\mathrm{k}} \text { Andrew }\end{array}$ \\
\hline
\end{tabular}

$\mathrm{SO}_{3}$ in air at $296 \mathrm{~K},(91 \pm 6)$ Torr $\mathrm{cm}^{2} \mathrm{~s}^{-1}$, is the average of those reported by Lovejoy and Hanson (1996) and Jayne et al. (1998).

The diffusivities of $\mathrm{H}_{2} \mathrm{SO}_{4}$ in $\mathrm{N}_{2}$ were reported to be $(85 \pm 15)$ Torr $\mathrm{cm}^{2} \mathrm{~s}^{-1}$ at $295 \mathrm{~K}$ (Lovejoy and Hanson, 1996), (71 \pm 5 ) Torr $\mathrm{cm}^{2} \mathrm{~s}^{-1}$ at $298 \mathrm{~K}$ (Hanson and Eisele, 2000), and $(67 \pm 1)$ Torr $\mathrm{cm}^{2} \mathrm{~s}^{-1}$ at $303 \mathrm{~K}$ (Pöschl et al., 1998). All three studies used flow tubes. As shown in Table 5, the diffusivity reported by Lovejoy and Hanson (1996) is in excellent agreement with the estimated value, while the values reported by Pöschl et al. (1998) and Hanson and Eisele (2000) agree with the estimated ones reasonably well (within $\sim 30 \%$ ). The preferred diffusivity of $\mathrm{H}_{2} \mathrm{SO}_{4}$ in $\mathrm{N}_{2}$ at $296 \mathrm{~K}$, $(74 \pm 10)$ Torr $\mathrm{cm}^{2} \mathrm{~s}^{-1}$, is the average of the three studies. No adjustment due to the temperature difference is done because difference in the diffusivities between $296 \mathrm{~K}$ and the temperatures at which the measurements were carried out is very small.

The diffusivity of $\mathrm{CH}_{3} \mathrm{SO}_{3} \mathrm{H}$ in $\mathrm{N}_{2}$ at $296 \mathrm{~K}$ was determined to be 60 Torr $\mathrm{cm}^{2} \mathrm{~s}^{-1}$ (Hanson, 2005). The uncertainty was not clearly stated in the original study, and the mea- sured value is $30 \%$ lower than that estimated using Fuller's method. The preferred diffusivity of $\mathrm{CH}_{3} \mathrm{SO}_{3} \mathrm{H}$ in $\mathrm{N}_{2}$, is recommended to be $(60 \pm 18)$ Torr $\mathrm{cm}^{2} \mathrm{~s}^{-1}$, and the uncertainty associated with the preferred value reflects the difference between the measured diffusivity and the estimated one.

\section{$3.4 \mathrm{O}_{3}, \mathrm{OH}, \mathrm{HO}_{2}$, and $\mathrm{H}_{2} \mathrm{O}_{2}$}

The diffusivity of $\mathrm{O}_{3}$ was only measured by one flow tube study, to be $(410 \pm 25)$ Torr $\mathrm{cm}^{2} \mathrm{~s}^{-1}$ at $295 \mathrm{~K}$ in He (Ivanov et al., 2007), and the estimated value by Fuller's method is $27 \%$ higher, as shown in Table 5. Unfortunately no measurement of the diffusivity of $\mathrm{O}_{3}$ in air (or $\mathrm{N}_{2} / \mathrm{O}_{2}$ ) has been performed and therefore no recommendation can be made, despite the central importance of $\mathrm{O}_{3}$ in the troposphere and stratosphere.

The diffusivities of $\mathrm{OH}$ radicals were measured at 218 $298 \mathrm{~K}$ in $\mathrm{He}$ and at 243-318 K in air (Liu et al., 2009). The results are in good agreement with the diffusivities in $\mathrm{He}$ (Bertram et al., 2001; Ivanov et al., 2007) and air (Ivanov et al., 2009) at room temperature reported by the same group, as shown in Table 5. The preferred diffusivity of $\mathrm{OH}$ radicals in 
Table 4. Summary of measured diffusivities of $\mathrm{NO}, \mathrm{NO}_{2}, \mathrm{NO}_{3}, \mathrm{~N}_{2} \mathrm{O}_{5}$ and $\mathrm{HONO}$, and comparison with the estimated values.

\begin{tabular}{llrrrrr}
\hline $\begin{array}{l}\text { Trace } \\
\text { gas }\end{array}$ & $\begin{array}{l}\text { Bath } \\
\text { gas }\end{array}$ & Reference & $\begin{array}{c}T \\
(\mathrm{~K})\end{array}$ & $D_{\mathrm{m}}$ & $D_{\mathrm{e}}$ & $\begin{array}{r}\left(D_{\mathrm{e}}-D_{\mathrm{m}}\right) / \\
D_{\mathrm{m}}(\%)\end{array}$ \\
\hline $\mathrm{NO}$ & $\mathrm{N}_{2}$ & a & 293 & 176 & 179 & 2 \\
\hline $\mathrm{NO}_{2}$ & $\mathrm{~N}_{2}$ & $\mathrm{~b}$ & 273 & 92 & 124 & 35 \\
& & $\mathrm{~b}$ & 283 & 98 & 132 & 35 \\
\hline $\mathrm{NO}_{3}$ & $\mathrm{~N}_{2}$ & $\mathrm{c}$ & 273 & $80 \pm 15$ & 127 & 59 \\
& $\mathrm{O}_{2}$ & $\mathrm{c}$ & 273 & $80 \pm 15$ & 127 & 59 \\
& $\mathrm{He}$ & $\mathrm{c}$ & 273 & $345 \pm 25$ & 510 & 48 \\
& $\mathrm{H} 2 \mathrm{O}$ & $\mathrm{c}$ & 273 & $120 \pm 15$ & 181 & 50 \\
\hline $\mathrm{N}_{2} \mathrm{O}_{5}$ & $\mathrm{~N}_{2}$ & $\mathrm{~d}$ & 296 & 65 & 94 & 45 \\
$\mathrm{HONO}$ & air & $\mathrm{e}$ & 296 & $114 \pm 5$ & 133 & 17 \\
& & $\mathrm{f}$ & 298 & $78 \pm 23$ & 135 & 73 \\
& $\mathrm{He}$ & $\mathrm{g}$ & 294 & $433 \pm 38$ & 507 & 17 \\
& & $\mathrm{~h}$ & 300 & $490 \pm 50$ & 525 & 7 \\
\hline
\end{tabular}

$D_{\mathrm{m}}$ : measured diffusivity (Torr $\mathrm{cm}^{2} \mathrm{~s}^{-1}$ ); $D_{\mathrm{e}}$ : estimated diffusivity (Torr $\mathrm{cm}^{2} \mathrm{~s}^{-1}$ ).

${ }^{a}$ Trautz and Muller (1935); ${ }^{b}$ Chambers and Sherwood (1937); ${ }^{c}$ Rudich et al. (1996); ${ }^{\mathrm{d}}$

Wagner et al. (2008); ${ }^{\mathrm{e}}$ Ferm and Sjodin (1985); ${ }^{\mathrm{f}}$ Benner et al. (1988); ${ }^{\mathrm{g}}$ Hirokawa et

al. (2008); ${ }^{\mathrm{h}}$ El Zein and Bedjanian (2012).

air at $296 \mathrm{~K},(179 \pm 20) \mathrm{Torr}_{\mathrm{cm}}^{2} \mathrm{~s}^{-1}$, is the average of values reported by Ivanov et al. (2007) and Liu et al. (2009).

The diffusivity of $\mathrm{HO}_{2}$ radicals in $\mathrm{He}$ was measured using flow tubes at $296 \mathrm{~K}$ (Ivanov et al., 2007; Lovejoy and Hanson, 1996), and the results reported by these two studies are in good agreement, as shown in Table 5. The diffusivity of $\mathrm{HO}_{2}$ radicals in $\mathrm{He}$, estimated using Fuller's method, is $40 \%$ larger than the measured values. The diffusivity of $\mathrm{HO}_{2}$ radicals in air (or $\mathrm{N}_{2} / \mathrm{O}_{2}$ ) has not been measured and thus no recommendation can be made. The uptake of $\mathrm{HO}_{2}$ radicals onto aerosol particles in the troposphere is suggested to be very fast and may have a significant impact on the oxidation capacity of the troposphere (Mao et al., 2013). Therefore an accurate determination of the diffusivity of $\mathrm{HO}_{2}$ in air (or $\mathrm{N}_{2} / \mathrm{O}_{2}$ ) is clearly of importance.

Only one study measured the diffusivity of $\mathrm{H}_{2} \mathrm{O}_{2}$ (in air), and a value of $(143 \pm 3) \mathrm{Torr}^{2} \mathrm{~s}^{-1}$ at $333 \mathrm{~K}$ was reported (McMurtrie and Keyes, 1948). The estimated diffusivity using Fuller's method, is 27\% larger than the measured value. The preferred diffusivity of $\mathrm{H}_{2} \mathrm{O}_{2}$ in air is $(143 \pm 43)$ Torr $\mathrm{cm}^{2} \mathrm{~s}^{-1}$ at $333 \mathrm{~K}$ and $(116 \pm 35)$ Torr $\mathrm{cm}^{2} \mathrm{~s}^{-1}$ at $296 \mathrm{~K}$. An uncertainty of $\pm 30 \%$ is given for the preferred values, taking into account the difference between the measured and estimated values.

\subsection{Halogen species}

\subsubsection{HOX and HX}

The diffusivity of $\mathrm{HOBr}$ was measured to be $(237 \pm 1)$ Torr $\mathrm{cm}^{2} \mathrm{~s}^{-1}$ at $255 \mathrm{~K}$ (Adams et al., 2002) and $(319 \pm 48)$ Torr $\mathrm{cm}^{2} \mathrm{~s}^{-1}$ at $274 \mathrm{~K}$ (Fickert et al., 1999) in
$\mathrm{He}$, and (84 \pm 7) Torr $\mathrm{cm}^{2} \mathrm{~s}^{-1}$ in $\mathrm{N}_{2}$ at $274 \mathrm{~K}$ (Fickert et al., 1999), using flow tubes. As shown in Table 6, the estimated diffusivity using Fuller's method is $\sim 10 \%$ larger than the measured value for $\mathrm{HOBr}$ in $\mathrm{N}_{2}$. The preferred diffusivity of $\mathrm{HOBr}$ in $\mathrm{N}_{2}$ at $274 \mathrm{~K},(84 \pm 9)$ Torr $\mathrm{cm}^{2} \mathrm{~s}^{-1}$, is based on the measurement of Fickert et al. (1999), and the uncertainty of the preferred value reflects the difference $(\sim 10 \%)$ between the measurement and the estimation. To the best of our knowledge, the diffusivity of $\mathrm{HOCl}$ has not been reported.

The diffusivity of $\mathrm{HOI}$ in $\mathrm{He}$ was measured to be $(191 \pm 38)$ Torr $^{2} \mathrm{~cm}^{-1}$ at $243 \mathrm{~K}$ and $(225 \pm 12)$ Torr $^{2} \mathrm{~s}^{-1}$ at $253 \mathrm{~K}$ (Holmes et al., 2001), and the estimated values using Fuller's method are $~ 30 \%$ larger. No measurement of the diffusivity in air $/ \mathrm{N}_{2} / \mathrm{O}_{2}$ has been reported. The diffusivities of $\mathrm{HOBr}$ and $\mathrm{HOI}$ in gaseous $\mathrm{H}_{2} \mathrm{O}$ were also measured (Adams et al., 2002; Holmes et al., 2001), and the estimated values using Fuller's method are $110 \%$ and $194 \%$ larger than the measured diffusivities in $\mathrm{H}_{2} \mathrm{O}$, as shown in Table 6. In contrast, the estimated diffusivities of $\mathrm{HOBr}$ in $\mathrm{He}$ and $\mathrm{N}_{2}$ and of $\mathrm{HOI}$ in $\mathrm{He}$ are in reasonably good agreement with the measured values. This may indicate that intermolecular interaction may occur between $\mathrm{HOBr} / \mathrm{HOI}$ and $\mathrm{H}_{2} \mathrm{O}$ molecules, thus slowing down the diffusion.

The diffusivities of $\mathrm{HCl}$ in $\mathrm{N}_{2}$ were measured in the temperature range of 324-523 K (Mian et al., 1969), and the difference between the measured and estimated values are $<20 \%$, as shown in Table 6 . If the diffusivity measured at $324 \mathrm{~K}$ is adjusted to that at $296 \mathrm{~K}$ using Eq. (16), it gives a value of $113 \mathrm{Torr}^{2} \mathrm{~s}^{-1}$. This agrees well with the diffusivity $\left(122 \mathrm{Torr} \mathrm{cm}^{2} \mathrm{~s}^{-1}\right)$ of $\mathrm{HCl}$ measured in air at $296 \mathrm{~K}$ using denuders (Matusca et al., 1984). The preferred diffusivity of 
Table 5. Summary of measured diffusivities of $\mathrm{SO}_{2}, \mathrm{SO}_{3}, \mathrm{H}_{2} \mathrm{SO}_{4}, \mathrm{O}_{3}, \mathrm{OH}, \mathrm{HO}_{2}$ and $\mathrm{H}_{2} \mathrm{O}_{2}$, and comparison with the estimated values.

\begin{tabular}{llrrrrr}
\hline $\begin{array}{l}\text { Trace } \\
\text { gas }\end{array}$ & $\begin{array}{l}\text { Bath } \\
\text { gas }\end{array}$ & Reference & \multicolumn{1}{c}{$T$} & $D_{\mathrm{m}}$ & $D_{\mathrm{e}}$ & $\begin{array}{r}\left(D_{\mathrm{e}}-D_{\mathrm{m}}\right) / \\
D_{\mathrm{m}}(\%)\end{array}$ \\
\hline $\mathrm{SO}_{2}$ & air & $\mathrm{a}$ & 263 & 79 & 78 & -1 \\
& & $\mathrm{~b}$ & 293 & 85 & 93 & 9 \\
& & $\mathrm{c}$ & 298 & 103 & 96 & -7 \\
\hline $\mathrm{SO}_{3}$ & $\mathrm{~N}_{2}$ & $\mathrm{~d}$ & 295 & $87 \pm 8$ & 95 & 9 \\
& & $\mathrm{e}$ & 300 & $95 \pm 3$ & 98 & 3 \\
\hline $\mathrm{H}_{2} \mathrm{SO}_{4}$ & $\mathrm{~N}_{2}$ & $\mathrm{~d}$ & 295 & $85 \pm 15$ & 86 & 1 \\
& & $\mathrm{f}$ & 303 & $67 \pm 1$ & 89 & 33 \\
& & $\mathrm{~g}$ & 298 & $71 \pm 5$ & 87 & 23 \\
\hline $\mathrm{CH}_{3} \mathrm{SO}_{3} \mathrm{H}$ & $\mathrm{N}$ & $\mathrm{h}$ & 296 & 60 & 78 & 30 \\
\hline $\mathrm{O}_{3}$ & $\mathrm{He}$ & $\mathrm{i}$ & 296 & $410 \pm 25$ & 522 & 27 \\
\hline $\mathrm{OH}^{2}$ & $\mathrm{He}$ & $\mathrm{i}$ & 296 & $663 \pm 25$ & 770 & 16 \\
& & $\mathrm{j}$ & 296 & $662 \pm 32$ & 770 & 16 \\
& & $\mathrm{k}$ & 298 & $662 \pm 32$ & 780 & 18 \\
\hline $\mathrm{N}_{2} \mathrm{O}_{2}$ & air & $\mathrm{i}$ & 296 & $165 \pm 20$ & 221 & 34 \\
\hline $\mathrm{HO}_{2}$ & & $\mathrm{k}$ & 298 & $192 \pm 20$ & 224 & 17 \\
\hline & $\mathrm{He}$ & $\mathrm{i}$ & 296 & $405 \pm 50$ & 587 & 45 \\
& & $\mathrm{i}$ & 296 & $430 \pm 30$ & 587 & 37 \\
\hline
\end{tabular}

$D_{\mathrm{m}}$ : measured diffusivity (Torr $\mathrm{cm}^{2} \mathrm{~s}^{-1}$ ); $D_{\mathrm{e}}$ : estimated diffusivity $\left(\operatorname{Torr~}_{\mathrm{cm}}^{2} \mathrm{~s}^{-1}\right.$ ).

${ }^{\mathrm{a}}$ Mason and Monchick (1962); ${ }^{\mathrm{b}}$ Andrew (1955); ${ }^{\mathrm{c}}$ Fish and Durham (1971); ${ }^{\mathrm{d}}$ Lovejoy and

Hanson (1996); ${ }^{\mathrm{e}}$ Jayne et al. (1998); ${ }^{\mathrm{f}}$ Pöschl et al. (1998); ${ }^{\mathrm{g}}$ Hanson and Eisele (2000); ${ }^{\mathrm{h}}$ Hanson

(2005); ${ }^{\mathrm{i}}$ Ivanov et al. (2007); ${ }^{\mathrm{j}}$ Bertram et al. (2001); ${ }^{\mathrm{k}}$ Liu et al. (2009); ${ }^{\mathrm{B}}$ Bedjanian et al. (2005);

${ }^{\mathrm{m}}$ McMurtrie and Keyes (1948).

$\mathrm{HCl}$ in $\mathrm{N}_{2}$ at $296 \mathrm{~K},(118 \pm 7)$ Torr $\mathrm{cm}^{2} \mathrm{~s}^{-1}$, is the average of the values reported by Matusca et al. (1984) at $296 \mathrm{~K}$ and Mian et al. (1969) after being extrapolated to $296 \mathrm{~K}$.

Only one study reported the diffusivity of $\mathrm{HBr}$, which was measured in $\mathrm{N}_{2}$ from 336 to $525 \mathrm{~K}$ (Mian et al., 1969). As shown in Table 6, the differences between the measured and estimated diffusivities are usually $<20 \%$. The preferred diffusivity of $\mathrm{HBr}$ in $\mathrm{N}_{2},(95 \pm 29)$ Torr $\mathrm{cm}^{2} \mathrm{~s}^{-1}$, is an extrapolation of the measured value at $336 \mathrm{~K}$ by Mian et al. (1969) to $296 \mathrm{~K}$ using Eq. (16), and the uncertainty reflects the difference between the measured and estimated diffusivities of $\mathrm{HBr}$ in $\mathrm{N}_{2}$ at $336 \mathrm{~K}$.

\subsubsection{Nitrogen-containing halogen species}

The diffusivities of $\mathrm{ClNO}_{2}$ in $\mathrm{N}_{2}$ and He were measured at $275 \mathrm{~K}$ in a flow tube study (Fickert et al., 1998), and the agreement with estimated values is within $20 \%$. The preferred diffusivities of $\mathrm{ClNO}_{2}$ in $\mathrm{N}_{2}$ are recommended to be $(75 \pm 15)$ Torr $\mathrm{cm}^{2} \mathrm{~s}^{-1}$ at $275 \mathrm{~K}$ and $(85 \pm 17)$ Torr $\mathrm{cm}^{2} \mathrm{~s}^{-1}$ at $296 \mathrm{~K}$, based on the measurement of Fickert et al. (1998). The assigned uncertainty reflects the difference between the measured and estimated diffusivity at $275 \mathrm{~K}$. The diffusivi- ties of $\mathrm{ClONO}_{2}$ or $\mathrm{BrONO}_{2}$ have not been reported, despite their importance in the stratosphere and possibly also in the troposphere.

\subsection{3 $\mathrm{X}_{2}$ and $\mathrm{XY}$}

The diffusivity of $\mathrm{Cl}_{2}$ in air was reported to be $(94 \pm 2)$ Torr $\mathrm{cm}^{2} \mathrm{~s}^{-1}$ at $293 \mathrm{~K}$ (Andrew, 1955). Though the measurement is in excellent agreement with the estimation, an uncertainty of $\pm 10 \%$ is given to the preferred value at $296 \mathrm{~K}$, i.e. $(94 \pm 10)$ Torr $\mathrm{cm}^{2} \mathrm{~s}^{-1}$. The diffusivities of $\mathrm{Br}_{2}$ in air was measured to be $(69 \pm 3)$ Torr $\mathrm{cm}^{2} \mathrm{~s}^{-1}$ at $293 \mathrm{~K}$ (Andrew, 1955), (80 \pm 3 ) Torr $\mathrm{cm}^{2} \mathrm{~s}^{-1}$ at $301 \mathrm{~K}$ (Brockett, 1966), and $(81 \pm 1)$ Torr $\mathrm{cm}^{2} \mathrm{~s}^{-1}$ at $298 \mathrm{~K}$ (Lugg, 1968). As shown in Table 6, all three measurements are in good agreement with the estimation. The preferred diffusivity of $\mathrm{Br}_{2}$ in air at $296 \mathrm{~K},(75 \pm 6)$ Torr $\mathrm{cm}^{2} \mathrm{~s}^{-1}$, is the average of the values reported by Andrew (1955), Brockett (1966) and Lugg (1968). The reported diffusivities of $\mathrm{I}_{2}$ in air at $298 \mathrm{~K}$ and in $\mathrm{N}_{2}$ at $273 \mathrm{~K}$ (Trautz and Muller, 1935) agree reasonably well with the estimated values (within $\pm 20 \%$ ). The preferred diffusivity of $I_{2}$ in air at $298 \mathrm{~K},(64 \pm 13)$ Torr $\mathrm{cm}^{2} \mathrm{~s}^{-1}$, is based on the value reported by Trautz and Muller (1935). 
Table 6. Summary of measured diffusivities of halogen species, and comparison with the estimated values.

\begin{tabular}{llrrrrr}
\hline $\begin{array}{l}\text { Trace } \\
\text { gas }\end{array}$ & Bath & Reference & \multicolumn{1}{c}{$T$} & $D_{\mathrm{m}}$ & $D_{\mathrm{e}}$ & $\left(D_{\mathrm{e}}-D_{\mathrm{m}}\right) /$ \\
$D_{\mathrm{m}}(\%)$
\end{tabular}

The diffusivities of $\mathrm{ICl}$ in He measured using a flow tube at 278 and $293 \mathrm{~K}$ (Braban et al., 2007) show good agreement with the estimated values. The discrepancy between measured and estimated diffusivities for $\mathrm{ICl}$ in $\mathrm{H}_{2} \mathrm{O}$ is significantly larger than that in He. Similar discrepancies were also observed for $\mathrm{HOBr}$ and $\mathrm{HIO}$ in $\mathrm{H}_{2} \mathrm{O}$, as discussed in Sect. 3.5.1, and this may suggest that in general Fuller's method works better for diffusivities in $\mathrm{N}_{2}, \mathrm{O}_{2}$, air and $\mathrm{He}$ than that in gaseous $\mathrm{H}_{2} \mathrm{O}$. The diffusivity of $\mathrm{BrCl}$ or $\mathrm{ICl}$ in air $/ \mathrm{N}_{2} / \mathrm{O}_{2}$ has not been reported.

\subsection{Temperature dependence of diffusivities}

Only a few studies measured the diffusivities of atmospheric reactive trace gases at several temperatures. The diffusivities of $\mathrm{NH}_{3}, \mathrm{HCl}$ and $\mathrm{HBr}$ in $\mathrm{N}_{2}$ were measured from $\sim 300$ to $>500 \mathrm{~K}$. As shown in Tables 3 and 6, over the broad temperature ranges investigated, the measured diffusivities agree well with the estimated values using Fuller's method. However, the temperature ranges $(300-500 \mathrm{~K})$ in which the diffusivities of $\mathrm{NH}_{3}, \mathrm{HCl}$ and $\mathrm{HBr}$ were determined are of little atmospheric relevance.

Using a flow tube, Liu et al. (2009) measured the diffusivities of $\mathrm{OH}$ radicals in air over the range of $243-318 \mathrm{~K}$. 


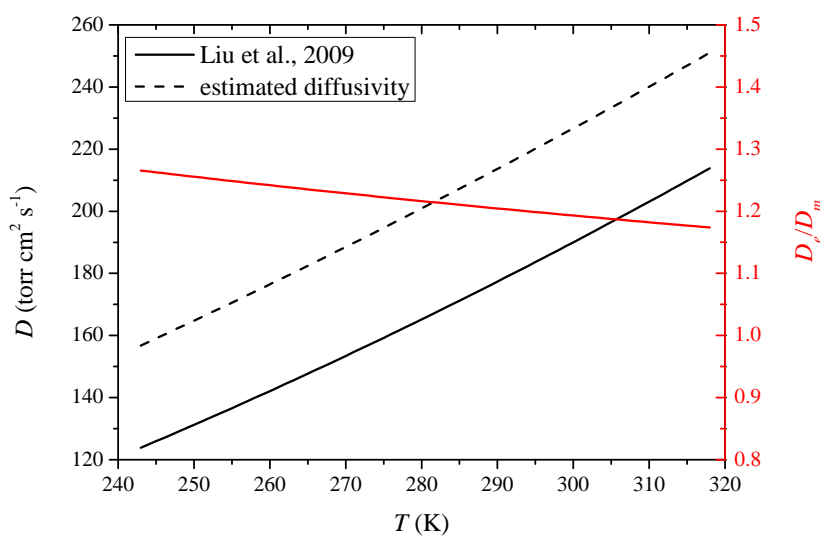

Figure 2. Temperature dependence of the diffusivity of $\mathrm{OH}$ radicals in air: comparison of measured diffusivity (Liu et al., 2009, black solid curve, left $y$ axis) with estimated values (black dashed curve, left $y$ axis). The ratios of estimated diffusivities to the measured ones (red curve, right $x$ axis) are also plotted as a function of temperature.

The diffusivities reported by Liu et al. (2009) and those estimated using Fuller's method are plotted in Fig. 2 as a function of temperature. The ratios of the estimated diffusivity to the measured one (red curve, right $y$ axis) are also shown in Fig. 2, suggesting that Fuller's method can predict the diffusivities of $\mathrm{OH}$ radicals over a broad temperature range within $\pm 30 \%$. The diffusivities of most of atmospheric reactive trace gases have not been measured at different temperatures, although the temperature dependence may be reasonably well estimated using Fuller's method.

\section{Conclusions}

The critical role of heterogeneous reactions in atmospheric chemistry has been widely accepted, and the necessity of adopting consistent terminology and having high quality of kinetic data have also been well recognised (Ammann et al., 2013; Crowley et al., 2010; Kolb et al., 2010; Pöschl et al., 2007; Sander et al., 2011). The diffusion of gas molecules towards the surface is the first step in a heterogeneous reaction, and it can influence and sometimes even control the overall rate of the uptake of a trace gas onto the surface. However, to the best of our knowledge, there is no database of the gas phase diffusion coefficients of atmospheric reactive trace gases.

In this work we have compiled and evaluated the available experimental data for the diffusivities of atmospheric inorganic reactive trace gases. The measured diffusivities are also compared with those estimated using Fuller's semi-empirical method. It is found that Fuller's method can typically estimate the diffusivities to within $\pm 30 \%$. Therefore, in cases where the diffusivity of a trace gas has not been measured,
Fuller's method can be used to estimate the diffusion coefficient.

The preferred diffusivities together with estimated uncertainties are tabulated to provide a quick and simple overview of the data currently available. This compilation/evaluation is also uploaded online (https://sites.google. com/site/mingjintang/home/diffusion), enabling further updates when new data become available. It should be noted that further measurements may change the uncertainties and/or the currently preferred values. Another aim of this work is to help identify and highlight areas of uncertainty or lack of data, therefore stimulating further measurements. We have started to compile and evaluate the diffusion coefficients of organic species, which will be published in another review in the near future.

Acknowledgements. We would like to thank J. Crowley (Max Planck Institute for Chemistry, Germany) for providing his collection of diffusion coefficient data, which forms the basis of this paper. Financial support by EPSRC grant number EP/I01473X/1 is acknowledged. M. J. Tang and M. Kalberer also thank the Isaac Newton Trust (Trinity College, University of Cambridge, UK) for financial support.

Edited by: S. A. Nizkorodov

\section{References}

Abbatt, J., George, C., Melamed, M., Monks, P., Pandis, S., and Rudich, Y.: New Directions: Fundamentals of atmospheric chemistry: Keeping a three-legged stool balanced, Atmos. Environ., 84, 390-391, 2014.

Abbatt, J. P. D.: Interactions of atmospheric trace gases with ice surfaces: Adsorption and reaction, Chem. Rev., 103, 4783-4800, 2003.

Abbatt, J. P. D. and Molina, M. J.: Heterogeneous interactions of $\mathrm{ClONO}_{2}$ and $\mathrm{HCl}$ on nitric-acid trihydrate at $202 \mathrm{~K}$, J. Phys. Chem., 96, 7674-7679, 1992.

Abbatt, J. P. D., Lee, A. K. Y., and Thornton, J. A.: Quantifying trace gas uptake to tropospheric aerosol: recent advances and remaining challenges, Chem. Soc. Rev., 41, 6555-6581, 2012.

Adams, J. W., Holmes, N. S., and Crowley, J. N.: Uptake and reaction of $\mathrm{HOBr}$ on frozen and dry $\mathrm{NaCl} / \mathrm{NaBr}$ surfaces between 253 and 233 K, Atmos. Chem. Phys., 2, 79-91, doi:10.5194/acp2-79-2002, 2002.

Adams, J. W., Rodriguez, D., and Cox, R. A.: The uptake of $\mathrm{SO}_{2}$ on Saharan dust: a flow tube study, Atmos. Chem. Phys., 5, 26792689, doi:10.5194/acp-5-2679-2005, 2005.

Ammann, M., Kalberer, M., Jost, D. T., Tobler, L., Rossler, E., Piguet, D., Gaggeler, H. W., and Baltensperger, U.: Heterogeneous production of nitrous acid on soot in polluted air masses, Nature, 395, 157-160, 1998.

Ammann, M., Cox, R. A., Crowley, J. N., Jenkin, M. E., Mellouki, A., Rossi, M. J., Troe, J., and Wallington, T. J.: Evaluated kinetic and photochemical data for atmospheric chemistry: Volume VI - heterogeneous reactions with liquid substrates, Atmos. Chem. Phys., 13, 8045-8228, doi:10.5194/acp-13-8045-2013, 2013. 
Andrew, S. P. S.: A simple method of measuring gasoeus diffusion coefficients, Chem. Eng. Sci., 4, 269-272, 1955.

Bedjanian, Y., Lelievre, S., and Le Bras, G.: Experimental study of the interaction of $\mathrm{HO}_{2}$ radicals with soot surface, Phys. Chem. Chem. Phys., 7, 334-341, 2005.

Benner, C. L., Eatough, N. L., Lewis, E. A., Eatough, D. J., Huang, A. A., and Ellis, E. C.: Diffusion-coefficients for ambient nitric acid and nitrous acids from denuder experiments in the 1985 nitrofen species methods comparison study, Atmos. Environ., 22, 1669-1672, 1988.

Berezhnoi, A. N. and Semenov, A. V.: Binary Diffusion Coefficients of Liquid Vapors in Gases, Begell House, Inc., New York, 1997.

Bertram, A. K., Ivanov, A. V., Hunter, M., Molina, L. T., and Molina, M. J.: The reaction probability of $\mathrm{OH}$ on organic surfaces of tropospheric interest, J. Phys. Chem. A, 105, 9415-9421, 2001.

Braban, C. F., Adams, J. W., Rodriguez, D., Cox, R. A., Crowley, J. N., and Schuster, G.: Heterogeneous reactions of HOI, ICl and IBr on sea salt and sea salt proxies, Phys. Chem. Chem. Phys., 9, 3136-3148, 2007.

Braman, R. S., Shelley, T. J., and McClenny, W. A.: Tungstic acid for pre-concentration and determination of gaseous and particulate ammonia and nitric-acid in ambient air, Anal. Chem., 54, 358-364, 1982.

Brockett, C. P.: Apparatus for the quantitative observation of gaseous diffusion, J. Chem. Educ., 43, 207-210, 1966.

Chambers, F. S. and Sherwood, T. K.: Absorption of Nitrogen Dioxide by Aqueous Solutions, Ind. Eng. Chem., 29, 1415-1422, 1937.

Crowley, J. N., Ammann, M., Cox, R. A., Hynes, R. G., Jenkin, M. E., Mellouki, A., Rossi, M. J., Troe, J., and Wallington, T. J.: Evaluated kinetic and photochemical data for atmospheric chemistry: Volume V - heterogeneous reactions on solid substrates, Atmos. Chem. Phys., 10, 9059-9223, doi:10.5194/acp-10-90592010, 2010.

Cziczo, D. J., Froyd, K. D., Gallavardin, S. J., Moehler, O., Benz, S., Saathoff, H., and Murphy, D. M.: Deactivation of ice nuclei due to atmospherically relevant surface coatings, Environ. Res. Lett., 4, 044013, doi:10.1088/1748-9326/4/4/044013, 2009.

Davidovits, P., Hu, J. H., Worsnop, D. R., Zahniser, M. S., and Kolb, C. E.: Entry of gas molecules into liquids, Faraday Discuss., 100, 65-81, 1995.

Davidovits, P., Kolb, C. E., Williams, L. R., Jayne, J. T., and Worsnop, D. R.: Update 1 of: Mass Accommodation and Chemical Reactions at Gas-Liquid Interfaces, Chem. Rev., 111, PR76PR109, 2011.

De Andrade, J. B., De Aragao, N. M., and Araujo, F. R. J.: Nitricacid air-diffusion coefficient: experimental-determination using a diffusion cell, Int. J. Environ. Anal. Chem., 49, 103-109, 1992.

Deiber, G., George, Ch., Le Calvé, S., Schweitzer, F., and Mirabel, Ph.: Uptake study of $\mathrm{ClONO}_{2}$ and $\mathrm{BrONO}_{2}$ by Halide containing droplets, Atmos. Chem. Phys., 4, 1291-1299, doi:10.5194/acp-41291-2004, 2004.

Dentener, F. J., Carmichael, G. R., Zhang, Y., Lelieveld, J., and Crutzen, P. J.: Role of mineral aerosol as a reactive surface in the global troposphere, J. Geophys. Res.-Atmos., 101, 2286922889, 1996.
Durham, J. L. and Stockburger, L.: Nitric acid-air diffusioncoefficient: experimental determination, Atmos. Environ., 20, 559$563,1986$.

Durham, J. L., Spiller, L. L., and Ellestad, T. G.: Nitric-acid nitrate aerosol mesurements by a diffusion denuder-a performance evaluation, Atmos. Environ., 21, 589-598, 1987.

Eatough, D. J., White, V. F., Hansen, L. D., Eatough, N. L., and Ellis, E. C.: Hydration of nitric-acid and its collection in the atmosphere by diffusion dunuders, Anal. Chem., 57, 743-748, 1985.

El Zein, A. and Bedjanian, Y.: Reactive Uptake of $\mathrm{HONO}$ to $\mathrm{TiO}_{2}$ Surface: "Dark" Reaction, J. Phys. Chem. A, 116, 3665-3672, 2012.

Fahey, D. W., Eubank, C. S., Hubler, G., and Fehsenfeld, F. C.: Evaluation of a catalytic reduction technique for the measurement of total reatcive odd-nitrogen $\mathrm{NO}_{\mathrm{y}}$ in the atmosphere, J. Atmos. Chem., 3, 435-468, 1985.

Ferm, M.: A $\mathrm{Na}_{2} \mathrm{CO}_{3}$-coated denuder and filter for determination of gaseous $\mathrm{HNO}_{3}$ and particle $\mathrm{NO}_{3}$ - in the atmosphere, Atmos. Environ., 20, 1193-1201, 1986.

Ferm, M. and Sjodin, A.: A sodium-carbonate coated dunuder for determination of nitrouc-acid in the atmosphere, Atmos. Environ., 19, 979-983, 1985.

Fickert, S., Helleis, F., Adams, J. W., Moortgat, G. K., and Crowley, J. N.: Reactive uptake of $\mathrm{ClNO}_{2}$ on aqueous bromide solutions, J. Phys. Chem. A, 102, 10689-10696, 1998.

Fickert, S., Adams, J. W., and Crowley, J. N.: Activation of $\mathrm{Br}_{2}$ and $\mathrm{BrCl}$ via uptake of $\mathrm{HOBr}$ onto aqueous salt solutions, J. Geophys. Res.-Atmos., 104, 23719-23727, 1999.

Finlayson-Pitts, B. J.: The tropospheric chemistry of sea salt: A molecular-level view of the chemistry of $\mathrm{NaCl}$ and $\mathrm{NaBr}$, Chem. Rev., 103, 4801-4822, 2003.

Fish, B. R. and Durham, J. L.: Diffusion coefficients of $\mathrm{SO}_{2}$ in air, Environ. Lett., 2, 13-21, 1971.

Fuller, E. N., Schettler, P. D., and Giddings, J. C.: New method for prediction of binary gas-phase diffusion coefficients, Ind. Eng. Chem., 58, 18-27, 1966.

Fuller, E. N., Ensley, K., and Giddings, J. C.: Diffusion of halogenated hydrocarbons in helium. The effect of structure on collision cross sections, J. Phys. Chem., 73, 3679-3685, 1969.

Gard, E. E., Kleeman, M. J., Gross, D. S., Hughes, L. S., Allen, J. O., Morrical, B. D., Fergenson, D. P., Dienes, T., Galli, M. E., Johnson, R. J., Cass, G. R., and Prather, K. A.: Direct observation of heterogeneous chemistry in the atmosphere, Science, 279 , 1184-1187, 1998.

George, I. J. and Abbatt, J. P. D.: Heterogeneous oxidation of atmospheric aerosol particles by gas-phase radicals, Nat. Chem., 2, 713-722, 2010.

Gershenzon, Y. M., Grigorieva, V. M., Ivanov, A. V., and Remorov, R. G.: $\mathrm{O}_{3}$ and $\mathrm{OH}$ sensitivity to heterogeneous sinks of $\mathrm{HO}_{\mathrm{x}}$ and $\mathrm{CH}_{3} \mathrm{O}_{2}$ on aerosol particles, Faraday Discuss., 100, 83-100, 1995.

Ghosh, S.: On the diffusibity of trace gases under strataspherici conditions, J. Atmos. Chem., 17, 391-397, 1993.

Gordon, M.: References to experimental data on diffusion coefficients of binary gas mixtures, National Engineering Laboratory, Glasgow, UK, 1977.

Hallquist, M., Stewart, D. J., Baker, J., and Cox, R. A.: Hydrolysis of $\mathrm{N}_{2} \mathrm{O}_{5}$ on submicron sulfuric acid aerosols, J. Phys. Chem. A, 104, 3984-3990, 2000. 
Hanson, D. R.: Mass accommodation of $\mathrm{H}_{2} \mathrm{SO}_{4}$ and $\mathrm{CH}_{3} \mathrm{SO}_{3} \mathrm{H}$ on water-sulfuric acid solutions from $6 \%$ to $97 \%$ RH, J. Phys. Chem. A, 109, 6919-6927, 2005.

Hanson, D. R. and Eisele, F.: Diffusion of $\mathrm{H}_{2} \mathrm{SO}_{4}$ in humidified nitrogen: Hydrated $\mathrm{H}_{2} \mathrm{SO}_{4}$, J. Phys. Chem. A, 104, 1715-1719, 2000.

Hanson, D. R. and Kosciuch, E.: The NH3 Mass Accommodation Coefficient for Uptake onto Sulfuric Acid Solutions, J. Phys. Chem. A, 107, 2199-2208, 2003.

Hanson, D. R., Burkholder, J. B., Howard, C. J., and Ravishankara, A. R.: Measurement of $\mathrm{OH}$ and $\mathrm{HO}_{2}$ Radical Uptake Coefficients on Water and Sulfuric-Acid Surfaces, J. Phys. Chem., 96, 49794985, 1992.

Hirokawa, J., Kato, T., and Mafune, F.: Uptake of Gas-Phase Nitrous Acid by $\mathrm{pH}$-Controlled Aqueous Solution Studied by a Wetted Wall Flow Tube, J. Phys. Chem. A, 112, 12143-12150, 2008.

Holmes, N. S., Adams, J. W., and Crowley, J. N.: Uptake and reaction of $\mathrm{HOI}$ and $\mathrm{IONO}_{2}$ on frozen and dry $\mathrm{NaCl} / \mathrm{NaBr}$ surfaces and $\mathrm{H}_{2} \mathrm{SO}_{4}$, Phys. Chem. Chem. Phys., 3, 1679-1687, 2001.

Huthwelker, T., Ammann, M., and Peter, T.: The uptake of acidic gases on ice, Chem. Rev., 106, 1375-1444, 2006.

Ivanov, A. V., Trakhtenberg, S., Bertram, A. K., Gershenzon, Y. M., and Molina, M. J.: $\mathrm{OH}, \mathrm{HO}_{2}$, and ozone gaseous diffusion coefficients, J. Phys. Chem. A, 111, 1632-1637, 2007.

Jayne, J. T., Poschl, U., Chen, Y., Dai, D., Molina, L. T., Worsnop, D. R., Kolb, C. E., and Molina, M. J.: Pressure and Temperature Dependence of the Gas-Phase Reaction of $\mathrm{SO}_{3}$ with $\mathrm{H}_{2} \mathrm{O}$ and the Heterogeneous Reaction of $\mathrm{SO}_{3}$ with $\mathrm{H}_{2} \mathrm{O} / \mathrm{H}_{2} \mathrm{SO}_{4}$ Surfaces, J. Phys. Chem. A, 101, 10000-10011, 1998.

Kolb, C. E., Cox, R. A., Abbatt, J. P. D., Ammann, M., Davis, E. J., Donaldson, D. J., Garrett, B. C., George, C., Griffiths, P. T., Hanson, D. R., Kulmala, M., McFiggans, G., Pöschl, U., Riipinen, I., Rossi, M. J., Rudich, Y., Wagner, P. E., Winkler, P. M., Worsnop, D. R., and O' Dowd, C. D.: An overview of current issues in the uptake of atmospheric trace gases by aerosols and clouds, Atmos. Chem. Phys., 10, 10561-10605, doi:10.5194/acp-10-10561-2010, 2010.

Laskin, A., Iedema, M. J., Ichkovich, A., Graber, E. R., Taraniuk, I., and Rudich, Y.: Direct observation of completely processed calcium carbonate dust particles, Faraday Discuss., 130, 453-468, 2005.

Lelieveld, J. and Crutzen, P. J.: Influences of cloud photochemical processes on tropospheric ozone, Nature, 343, 227-233, 1990.

Liu, Y., Ivanov, A. V., and Molina, M. J.: Temperature dependence of OH diffusion in air and He, Geophys. Res. Lett., 36, L03816, 10.1029/2008g1036170, 2009.

Lovejoy, E. R. and Hanson, D. R.: Kinetics and products of the reaction $\mathrm{SO}_{3}+\mathrm{NH}_{3}+\mathrm{N}_{2}$, J. Phys. Chem., 100, 4459-4465, 1996.

Lugg, G. A.: Diffusion coefficients of some organic and other vapors in air, Anal. Chem., 40, 1072-1077, 1968.

Mao, J., Fan, S., Jacob, D. J., and Travis, K. R.: Radical loss in the atmosphere from $\mathrm{Cu}-\mathrm{Fe}$ redox coupling in aerosols, Atmos. Chem. Phys., 13, 509-519, doi:10.5194/acp-13-509-2013, 2013.

Marrero, T. R. and Mason, E. A.: Gaseous Diffusion Coefficients, J. Phys. Chem. Ref. Data, 1, 3-118, 1972.

Mason, E. A. and Monchick, L.: Transport Properties of Polar-Gas Mixtures, J. Chem. Phys., 36, 2746-2757, 1962.
Matusca, P., Schwarz, B., and Bachmann, K.: Measurements of diurnal concentration variations of gaseous $\mathrm{HCl}$ in air in the subnanogram range, Atmos. Environ., 18, 1667-1675, 1984.

McMurtrie, R. L. and Keyes, F. G.: A measurement of the diffusion coefficient of hydrogen peroxide vapor into air, J. Am. Chem. Soc., 70, 3755-3758, 1948.

Mian, A. A., Coates, J., and Cordiner, J. B.: Binary gaseous diffusion coefficients of $\mathrm{N}_{2}-\mathrm{HCl}, \mathrm{A}-\mathrm{HBr}$ and $\mathrm{N}_{2}-\mathrm{HBr}$ systems as a function of temperature, Can. J. Chem. Eng., 47, 499-502, 1969.

Mogili, P. K., Kleiber, P. D., Young, M. A., and Grassian, V. H.: Heterogeneous uptake of ozone on reactive components of mineral dust aerosol: An environmental aerosol reaction chamber study, J. Phys. Chem. A, 110, 13799-13807, 2006.

Molina, M. J.: Polar ozone depletion (Nobel lecture), Angew. Chem. Int. Edit., 35, 1778-1785, 1996.

Monge, M. E., D’Anna, B., Mazri, L., Giroir-Fendler, A., Ammann, M., Donaldson, D. J., and George, C.: Light changes the atmospheic reactivity of soot, P. Natl. Acad. Sci. USA, 107, 66056609, 2010.

Murphy, D. M. and Fahey, D. W.: Mathematical treatment of the wall loss of a trace species in denuder and catalytic convertor tubes, Anal. Chem., 59, 2753-2759, 1987.

Nazaroff, W. W. and Cass, G. R.: Mass-transport aspects of pollutant removal at indoor surfaces, Environ. Int., 15, 567-584, 1989.

Pöschl, U., Canagaratna, M., Jayne, J. T., Molina, L. T., Worsnop, D. R., Kolb, C. E., and Molina, M. J.: Mass accommodation coefficient of $\mathrm{H}_{2} \mathrm{SO}_{4}$ vapor on aqueous sulfuric acid surfaces and gaseous diffusion coefficient of $\mathrm{H}_{2} \mathrm{SO}_{4}$ in $\mathrm{N}_{2} / \mathrm{H}_{2} \mathrm{O}$, J. Phys. Chem. A, 102, 10082-10089, 1998.

Pöschl, U., Rudich, Y., and Ammann, M.: Kinetic model framework for aerosol and cloud surface chemistry and gas-particle interactions - Part 1: General equations, parameters, and terminology, Atmos. Chem. Phys., 7, 5989-6023, doi:10.5194/acp-75989-2007, 2007.

Pöschl, U.: Gas-particle interactions of tropospheric aerosols: Kinetic and thermodynamic perspectives of multiphase chemical reactions, amorphous organic substances, and the activation of cloud condensation nuclei, Atmos. Res., 101, 562-573, 2011.

Pouvesle, N., Kippenberger, M., Schuster, G., and Crowley, J. N.: The interaction of $\mathrm{H}_{2} \mathrm{O}_{2}$ with ice surfaces between 203 and 233 K, Phys. Chem. Chem. Phys., 12, 15544-15550, 2010.

Ravishankara, A. R.: Heterogeneous and multiphase chemistry in the troposphere, Science, 276, 1058-1065, 1997.

Reid, R. C., Prausnitz, J. M., and Poling, B. E.: The Properties of Gases and Liquids, McGraw-Hill, Inc., New York, 1987.

Reitz, P., Spindler, C., Mentel, T. F., Poulain, L., Wex, H., Mildenberger, K., Niedermeier, D., Hartmann, S., Clauss, T., Stratmann, F., Sullivan, R. C., DeMott, P. J., Petters, M. D., Sierau, B., and Schneider, J.: Surface modification of mineral dust particles by sulphuric acid processing: implications for ice nucleation abilities, Atmos. Chem. Phys., 11, 7839-7858, doi:10.5194/acp-117839-2011, 2011.

Rossi, M. J.: Heterogeneous reactions on salts, Chem. Rev., 103, 4823-4882, 2003.

Rudich, Y., Talukdar, R. K., Imamura, T., Fox, R. W., and Ravishankara, A. R.: Uptake of $\mathrm{NO}_{3}$ on KI solutions: Rate coefficient for the $\mathrm{NO}_{3}+\mathrm{I}^{-}$reaction and gas-phase diffusion coefficients for $\mathrm{NO}_{3}$, Chem. Phys. Lett., 261, 467-473, 1996. 
Sander, S. P., Abbatt, J. P. D., Barker, J. R., Burkholder, J. B., Friedl, R. R., Golden, D. M., Huie, R. E., Kolb, C. E., Kurylo, M. J., Moortgat, G. K., Orkin, V. L., and Wine, P. H.: Chemical Kinetics and Photochemical Data for Use in Atmospheric Studies, Evaluation No. 17, JPL Publication 10-6, Jet Propulsion Lab., Pasadena, CA, 2011.

Shiraiwa, M., Pfrang, C., and Pöschl, U.: Kinetic multi-layer model of aerosol surface and bulk chemistry (KM-SUB): the influence of interfacial transport and bulk diffusion on the oxidation of oleic acid by ozone, Atmos. Chem. Phys., 10, 3673-3691, doi:10.5194/acp-10-3673-2010, 2010.

Solomon, S.: Stratospheric ozone depletion: A review of concepts and history, Rev. Geophys., 37, 275-316, 1999.

Spiller, L. L.: Determination of ammonia air diffusion-coefficient using nafion lined tube, Anal. Lett., 22, 2561-2573, 1989.

Stemmler, K., Ammann, M., Donders, C., Kleffmann, J., and George, C.: Photosensitized reduction of nitrogen dioxide on humic acid as a source of nitrous acid, Nature, 440, 195-198, 2006.

Sullivan, R. C., Guazzotti, S. A., Sodeman, D. A., and Prather, K. A.: Direct observations of the atmospheric processing of Asian mineral dust, Atmos. Chem. Phys., 7, 1213-1236, doi:10.5194/acp-7-1213-2007, 2007.

Sullivan, R. C., Moore, M. J. K., Petters, M. D., Kreidenweis, S. M., Roberts, G. C., and Prather, K. A.: Timescale for hygroscopic conversion of calcite mineral particles through heterogeneous reaction with nitric acid, Phys. Chem. Chem. Phys., 11, 7826-7837, 2009a.

Sullivan, R. C., Moore, M. J. K., Petters, M. D., Kreidenweis, S. M., Roberts, G. C., and Prather, K. A.: Effect of chemical mixing state on the hygroscopicity and cloud nucleation properties of calcium mineral dust particles, Atmos. Chem. Phys., 9, 33033316, doi:10.5194/acp-9-3303-2009, 2009 b.

Tang, M. J., Thieser, J., Schuster, G., and Crowley, J. N.: Kinetics and mechanism of the heterogeneous reaction of $\mathrm{N}_{2} \mathrm{O}_{5}$ with mineral dust particles, Phys. Chem. Chem. Phys., 14, 8551-8561, 2012.
Tang, M. J., Schuster, G., and Crowley, J. N.: Heterogeneous reaction of $\mathrm{N}_{2} \mathrm{O}_{5}$ with illite and Arizona test dust particles, Atmos. Chem. Phys., 14, 245-254, doi:10.5194/acp-14-245-2014, 2014.

Thornton, J. A., Braban, C. F., and Abbatt, J. P. D.: $\mathrm{N}_{2} \mathrm{O}_{5}$ hydrolysis on sub-micron organic aerosols: the effect of relative humidity, particle phase, and particle size, Phys. Chem. Chem. Phys., 5, 4593-4603, 2003.

Trautz, M. and Muller, W.: Friction, heat conduction and diffusion in gaseous mixtures XXXIII The correction of the hitherto evaporation method of measuring diffusion constants, Ann. Phys.Berlin, 22, 333-352, 1935.

Usher, C. R., Michel, A. E., and Grassian, V. H.: Reactions on mineral dust, Chem. Rev., 103, 4883-4939, 2003.

Vlasenko, A., Huthwelker, T., Gaggeler, H. W., and Ammann, M.: Kinetics of the heterogeneous reaction of nitric acid with mineral dust particles: an aerosol flow tube study, Phys. Chem. Chem. Phys., 11, 7921-7930, 2009.

Wagner, C., Hanisch, F., Holmes, N., de Coninck, H., Schuster, G., and Crowley, J. N.: The interaction of $\mathrm{N}_{2} \mathrm{O}_{5}$ with mineral dust: aerosol flow tube and Knudsen reactor studies, Atmos. Chem. Phys., 8, 91-109, doi:10.5194/acp-8-91-2008, 2008.

Wahner, A., Mentel, T. F., Sohn, M., and Stier, J.: Heterogeneous reaction of $\mathrm{N}_{2} \mathrm{O}_{5}$ on sodium nitrate aerosol, J. Geophys. Res.Atmos., 103, 31103-31112, 1998.

Weissman, S.: Estimation of diffusion coeffcients from viscocity measurements: Polar and polyatomic gases, J. Chem. Phys., 40, 3397-3406, 1964.

Worsnop, D. R., Zahniser, M. S., Kolb, C. E., Gardner, J. A., Watson, L. R., Vandoren, J. M., Jayne, J. T., and Davidovits, P. Temperature-Dependence of Mass Accommodation of $\mathrm{SO}_{2}$ and $\mathrm{H}_{2} \mathrm{O}_{2}$ on Aqueous Surfaces, J. Phys. Chem., 93, 1159-1172, 1989.

Zasypkin, A. Y., Grigor'eva, V. M., Korchak, V. N., and Gershenson, Y. M.: A formula for summing of kinetic resistances for mobile and stationary media: I. Cylindrical reactor, Kinet. Catal., 38, 772-781, 1997. 